\title{
Organizational and Individual Determinants of Employees' Intrapreneurship Behavior in Private Egyptian Organizations ${ }^{1}$
}

\author{
Dr. Ghada A. Atteya ${ }^{2}$
}

Prof. Aly A. Messallam ${ }^{3}$

\begin{abstract}
This research is interested in studying the role of some organizational and individual determinants in increasing employees' intrapreneurship behaviors. It also focuses on investigating the favorable situations upon which those determinants could enhance intrapreneurship behaviors. Specifically, the study investigates the effect of organizational climate for psychological safety, psychological ownership, achievement motivation, and big five personality traits on employees' risk taking, proactiveness and innovativeness behaviors. Furtheremore, it tests the moderating role of transformational leadership in strengthening the above direct relationships.

Using both of on-line and handled questionnaires, in addition of using hierarchical regression analysis, on a convenient sample of 495 employees working in different private sectors in Alexandria, the results came to full and partial supports of most of the study hypotheses, while rejecting others. The findings revealed significant positive effects of organizational climate for psychological safety, psychological ownership, achievement motivation, extraversion, emotional stability, conscientiousness, and agreeableness on intrapreneurship behaviors, while an unexpected negative relationship between openness to experience and those behaviors was revealed. Importantly, transformational leadership played the interactive role with most of those determinants in enhancing employees' intrapreneurship behaviors.
\end{abstract}

${ }^{1}$ Received in 18/11/2020, accepeted in 1/12/2020.

${ }^{2}$ Dr. Ghada Adel Atteya is currently Assistant Professor, Department of Business Administration, Faculty of Commerce, Alexandria University (Ghadaadel100_8@hotmail.com)

3 Prof. Aly Abdelhady Messallam is currently Professor of Organizational Studies, Department of Business Administration, Faculty of Commerce, Alexandria University (aly.messallam@alex.edu.eg) 
Keywords: Organizational Climate for Psychological Safety - Psychological Ownership Achievement Motivation - Big Five Dimensions of Personality - Employees' Intrapreneurship Behavior - Transformational Leadership.

\section{1- Introduction}

Catalysing Entrepreneurship for Job creation (World Bank, 2020), Egypt Innovate (Egypt Innovate, 2019), and Inno Egypt (Inno Egypt, 2017), are three main Egyptian projects. They aim at enabling a good environment for developing innovative projects, exposing Egyptian innovators to the local and global environment through an Egyptian electronic hub, and building a collective communities' system of entrepreneurship and innovation. In this context, the World Bank has praised Egypt's efforts in challenging the substantial issues for creating jobs, enhancing opportunities for entrepreneurship and growth of the private sector (World Bank, 2019a). It has also praised the increase in economic development rates in 2019 (World Bank, 2019b), and the number of macro and structural reform programs (World Bank, 2019c). Nevertheless all of these growing structural, macro and micro economic reforms, aiming at fostering entrepreneurship, innovative firms and start ups in Egypt, yet, more efforts are to be directed towards enhancing employees' intrapreneurship behavior as well. In other words, encouraging employees to take their responsibilities for playing the intrapreneurial role.

By reviewing the literature for supporting this claim, it was noted that Farrukh, Ying and Mansori's in their prior research (2016) have raised attention to the necessity of studying employees' intrapreneurship behavior inside existing organizations. Their call has led some recent researchers investigate its positive consequences, especially in transition and developing economies, such as increasing performance (Daneji and Bambale, 2019), and enhancing organizations' responses to the growing competition, in addition to facing the old managerial practices (Monfared; Khorakian; Shirazi and Maharati, 2019).

Other lines of research have been also interested in examining its antecedents, such as managerial support and rewards (Badoiu; SegarraCiprés and Escrig-Tena, 2020), organizational empowerement (Moghaddas; Tajafari and Nowkarizi, 2020), trust in managers, formal 
context of the work, intrapreneurs' age, gender, and educational level (Valka; Roseira and Campos, 2020). While some others have studied the processes by which antecedents may foster intrapreneurship (Aris; Rajah; Abdullah and Abdul Hamid, 2019; Farrukh; lee and Shahzad, 2019; Woo, 2018).

Interestingly, it was also noted that some other research have only focused on the innovativeness dimension, while neglecting the other two dimensions: proactiveness and risk taking (Khan; Ismail; Hussain and Alghazali, 2020). Whereas others have focused on applying their studies in different countries such as Pakistan (Farrukh, et al., 2019), South Africa (Schachtebeck; Groenewald and Nieuwenhuizen, 2019), Iran (Monfared, et al., 2019), and Latvia (Valka, et al., 2020).

Notably, although those recent studies have responded to the abovementioned call, and came to valuable results, again, in 2019, Farrukh and his colleagues have furtherly argued a close claim to the one introduced three years before (2016). They have concluded that a gap still exists in studying more employees' intrapreneurship behavior antecedents (Farrukh, et al., 2019). Furtheremore, another interesting note has been observed, in which there is a growing need for studying some moderator variables affecting those direct relationships (e. g. Razavi and Ab Aziz, 2017).

Thus, this urgent recent call for testing more antecedents and more interactive variables, has led the current researchers try to contribute to the accumulated knowledge of the intrapreneurship field. Hence, an overarching objective of the study is to examine more organizational and individual determinants boosting employees' intrapreneurship behaviors, in addition to investigating the conditions and situations, which may weaken or strengthen those relationships in Egyptian organizations.

\section{2- Research Problem}

The role of employees has changed radically over past years. They have turned to the role of being intrapreneurs and being more innovative, rather than simply being recipients (Nessen; Caniëls; Vos and de Jong, 2019). Hence, due to the importance of this emerging role, and the 
underresearched factors affecting this role, in addition to the inconclusive findings reached by prior research, more research is still needed. Therefore, the current study has got into an in-depth review in the literature to investigate more determinants enhancing employees' intrapreneurship behaviors, especially in developing countries. Accordingly, some important notes have been remarked as follows:

One of the most influential factors affecting intrapreneurship behavior was the existence of an organizational climate for psychological safety. In other words, being able to express one-self ideas, with no fear of punishments or any negative results to the individual's self image (Kahn, 1990). Obvious examples of the few recent studies that called for more investigation for the psychological safety climate at the organizational level, were the ones presented by Monfared and his colleagues (2019), and Andersson, Moen and Brett (2020). Thus, the current research would introduce this variable as a significant organizational determinant in increasing intrapreneurship behavior.

Psychological ownership has been also suggested to be another important determinant. Individuals who feel the sense of possessing their organization, would have positive behaviors and attitudes towards it. Although many scholars have found that psychological ownership positively affects organizational citizenship behaviors, organizational commitment, job satisfaction, organization-based selfesteem, and performance (O'Driscoll; Pierce and Coghlan, 2006; Pierce; Kostova and Dirks, 2001; 2002; Pierce; O'Driscoll and Coghlan, 2004; Van Dyne and Pierce, 2004); still, studies are to investigate its effects on employees' intapreneurship behavior (Mustafa; Martin and Hughes, 2016). Therefore, the current study would introduce psychological ownership as an individual determinant that needs more investigation.

Motivation has been also studied in recent qualitative and field research. Scholars were interested in studying the role of personal motivators, and motivation in increasing employees' intrapreneurship behavior (e. g. Nessen, et al., 2019; Sadeghpour; Cherabin; Shekari and Del, 2019; Ali; Mustapha; Jaafar; Hassan; and Ur Rehman, 2020). Though, this stream of research showed the important role of motivation, yet, the current study noted a lack in studying the role of achievement motivation in explaining employees' intrapreneurship 
behavior, in addition to the inconsistent results revealed by some prior research (Shaikh; Nili; Dwibedi and Madhavan, 2019; Razavi and Ab Aziz, 2017). Therefore, it would be argued that it became imperative studying the role of achievement motivation in enhacing employees' intrapreneurship behavior.

Additionally, the big five personality traits are introduced to be other interesting determinants that may affect employees' intrapreneurship behavior. By reviewing the literature, it was noted that those big five traits-intrapreneurship behaviors relationships are somewhat confusing. They were subjects to controversy, debatable analysis by scholars, who reached contradictory results (e. g. Alam; Kousar; Shabbir and Kaleem, 2020; Farrukh, et al, 2016; Rodrigues and Rebelo, 2019). Hence, it would be also imperative to furtherly investigate those relationships.

Moreover, another noteworthy remark is represented in the need for investigating the conditions that may strengthen or weaken the above relationships. While reviewing the literature for supporting this argument, it was found that increasing employees' intrapreneurship behavior needs an effective leadership and support from managers. This claim was also supported by some recent studies which investigated Transformational Leadership (TL) as an important leadership type in enhancing employees' intrapreneurship behavior in developed countries (e. g. Farrukh, et al., 2019; Watts; Steel and Den Hartog, 2020), and transition economies such as Pakistan (e.g. Khan, et al., 2020), and Tunisia (Boukamcha, 2019).

Although the above-mentioned studies were interested in studying the role of transformational leadership as a significant determinant for employees' intrapreneurship behavior either in developed or transition economies, yet its moderating role on the individual and organizational determinants-employees' intrapreneurship behavior relationships did not get enough interest. Interestingly, and relying on the researchers' review in the literature, it was found that the only study of (Razavi and $\mathrm{Ab}$ Aziz, 2017) revealed that transformational leadership moderated the relationship between each of proactiveness, risk-taking, and innovativeness and intrapreneurship intentions. Accordingly, the 
current study could claim that the proposed organizational and individual variables would be more powerful in leveling up employees' intrapreneurship behaviors, when moderated by transformational leadership.

Furtheremore, some other practical evidence about the importance of this phenomenon was also recorded. An example of those organizations which urge for implementing an effective policy to enable a good environment and useful tools to foster intrapreneurship was Lenovo Egypt (2020). This policy may include facing new challenges and opportunities by creating creativity and learning environment, empowering intrapreneurs, motivating and rewarding them, giving them the freedom to learn from mistakes, besides not being afraid from failure or punishments.

Therefore, and to sum up, this study represents an attempt to contribute theoretically to the intrapreneurship growing field of research, by investigating the role of organizational climate for psychological safety, psychological ownership, achievement motivation, and personality traits in explaining the variance in employees' intrapreneurship behavior. In addition to studying the moderating role of transformational leadership on these suggested relationships in some private Egyptian organizations. Futheremore, the current study would also offer a practical value, in which, it is an attempt to direct business practitioners' attention towards new tools for leveling up employees' intrapreneurship behavior. It would also raise their awareness towards enabling favorable conditions for increasing these positive behaviors inside their organizations.

Next section will elaborate the literature review and previous studies, upon which hypotheses of the study would be proposed, and model of the study would be introduced as follows:

\section{3- Litterature Review and Hypotheses Development}

Derived from the entrepreneurship research, intrapreneurship has been seen as a growing field of knowledge (Schachtebeck, et al., 2019). It may be referred to as the activities of entrepreneurship inside existing organizations (Antoncic and Hisrich, 2003; Farrukh, et al., 2019). It is also the human capital's result (Valka, et al., 2020), and the 
voluntary act of the employees that aims to perceive opportunities, generate novel ideas and create new products and lines of production (Valsania; Moriano and Molero, 2016).

As an apparent distinction between organizational and individual intrapreneurship levels, it can be seen that "entrepreneurial orientation", or "corporate entrepreneurship is related to the "topdown' process to encourage the activities of entrepreneurship at the organizational level. Whereas intrapreneurship at the individual level, is driven by employees and takes the 'bottom-up' process. It is seen as the psychological evaluation or assessment of the employees' behaviors, regarding their ability to involve in risk taking activities, in addition to their innovative and proactive behaviors (Moriano; Molero; Topa and Mangin, 2014; Schachtebeck, et al., 2019).

Therefore, and starting from the point of getting the benefits of employees' intapreneurship behavior, such as increasing performance, value and growth of the firms, it would be claimed that different organizations need to encourage and enable intrapeneurship at the individual level, freely and without fear of failure or punishment. They also need to create a good and safe environment for them to work, innovate, taking risks and being proactive. Accordingly, the current study tries to capture the organizational and individual factors affecting this behavior at the individual level, as will be elaborated in the following sections:

\section{3-1 Organizational Climate for Psychological Safety and Intrapreneurship}

Psychological safety, was first originated in Maslow's hierarchy needs, known as security needs (Maslow, 1943; Chen; Gao; Zheng and Ran, 2015). Organizational psychological safety is the type of perceptions, which employees share regarding the main charactersics of the organizational environment (Brown and Leigh, 1996). In their prior study, Schein and Bennis (1965) elaborated that psychological safety environment is vital for decreasing interpersonal risks, and making employees feel that they are safe to change their actions and behaviors in conditions of organizational changes. 
In this context, prior studies showed that enabling a favorable organizational environment is crucial for boosting intrapreneurship and employees' innovative behaviors (Bysted, 2013; Moriano et al., 2014). Other scholars declared that organizations need to build a culture of constructive failure, which enables employees having the freedom to make mistakes and fail, and not being punished if they came with proper ideas. It will also keep employees away from the negative consequences resulting from risk taking behaviors, and will motivate them to innovate (Buekensa, 2014; Newman; Donohue and Eva, 2017). Furtheremore, in a recent qualitative case study in Iran, Monfared and his colleagues (2019) have found that intrapreneurship behavior is directly related with environmental factors, including learning and adapting to change.

In another line of research, some other recent studies have also agreed that psychological safety is positively related to creativity implementation (Agarwal and Farndale, 2017), creative work involvement (Kark and Carmeli, 2009), and creativity (Frazier; Fainshmidt; Klinger; Pezeshkan and Vracheva, 2017). Additionally; Mahmoud; Ahmad and Poespowidjojo (2018), in their conceptual framework, have also suggested that psychological safety would affect intrapreneurship behavior positively.

As a step forward to a higher level of analysis, other researchers have proved the positive relationship between organizational climate for psychological safety and process innovativeness at the organizational level (Baer and Frese, 2003), and organizational intrapreneurship behaviors in small and medium enterprises in Norway (Andersson, et al., 2020). They have also revealed that low levels of psychological safety may prevent employees' involvement in creative behaviors (Baer and Frese, 2003).

So far, it was noted from the above discussion that these studies have agreed on the important role of organizational climate for psychological safety in affecting employees' intrapreneurship behavior positively, especially in developing countries (e. g. Monfared, et al., 2019). This positive relationship was also recorded at the higher level of analysis (e.g. Andersson, et al., 2020). Accordingly, and relying on the social 
exchange theory and the norm of reciprocity (Blau, 1964; Gouldner, 1960), the current study tries to add up to the first stream of research. It will argue that when employees feel safe trying new methods, making some mistakes, bringing up tough issues, they would then reciprocate these good relationships with their organization, and will react back by taking the risk to exhibit more innovative behaviors, and being more proactive. Hence, hypothesis one would be elaborated as follows:

H1: Organizational climate for psychological safety positively affects employees' intrapreneurship behavior.

\section{3-2 Psychological Ownership and Intrapreneurship}

As an attitude, psychological ownership is considered the state where individuals feel that the object or target of ownership is "theirs" (Van Dyne and Pierce, 2004). It is humanistic in nature, formed towards tangible or intangible objects or targets (Pierce, et al., 2001). Essentially, it has a possessiveness base, in addition to its motivational base. In other words, individuals feel the sense of having a home or a place, it also satisfies the feeling of self-identity, effectance, and selfefficacy, as three main individual needs (Pierce et al., 2001; 2002). Moreover and as a step forward; Avey; Avolio; Crossley and Luthans (2009), have extended the concept, and argued that employees experience both feelings of territoriality and promotivation when feeling psychological ownership towards the organization and its resources.

In this regard, Van Dyne and Pierce (2004) argued that although employees do not own the organization legally, still their ownership feelings towards the organization has many positive effects, such as employees' positive attitudes towards their organizations and jobs (O'Driscoll, et al., 2006; Pierce, et al. 2001; 2002; Pierce, et al., 2004; Van Dyne and Pierce, 2004). In addition to taking personal risks (Pierce, etal.,2001;2002), and increasing individual intrapreneurship behavior (Mustafa, et al., 2016; Sieger; Zellweger and Aquino, 2013).

Nevertheless, these several positive effects on employees' attitudes and behaviors, Mustafa and his colleagues (2016) have furtherely claimed that studies are to investigate more effects on intapreneurship behavior. Accordingly, few other research have responded to the call, 
and proved the psychological ownership-intrapreneurship behavior positive relationship in Nigeria (Daneji and Bamble, 2019), and Korea (Lee, Makri and Scandura, 2019).

Other veins of research have also revealed the positive role of some psychological ownership dimensions such as the sense of belongingness on intrapreneurship behavior (Badoiu et al, 2020), innovativeness and creativity (Slamti, 2020). Other studies have agreed that leadership selfefficacy is a predictor of intrapreneurship intentions (Shaikh, et al., 2019), and that employees' self-efficacy is related to their intrapreneurship intentions (Douglas and Fitzsimmons, 2013). Moreover, employees' entrepreneurial self-efficacy plays the interactive role with both financial and non-financial incentives in increasing their intrapreneurship behaviors (Jessri; Kosmidou and Ahuja, 2020).

Notably from the above discussion, it can be observed that most of the prior research (e. g. Daneji and Bamble, 2019; Lee, et al., 2019; Mustafa, et al., 2016) have used the common view of psychological ownership towards the organization presented by Pierce and his colleagues (2001; 2002; 2004). Whereas some other studies have only investigated the effect of some of the psychological ownership dimensions such as selfefficacy and sense of belongingness on intrapreneurship behavior (e.g. Slamti, 2020; Jessri, et al., 2020). Hence, the present study would take the extended prespective of psychological ownership (Avey, et al., 2009), and claims that employees' preventative and promotive psychological ownership will stimulate them engaging in intrapreneurship behaviors in several ways. Firstly, when feeling their possessiveness to their organization, in addition to their feelings of contributing to the organization's goals and success as their own. Furteremore, when being accountable for their actions, believing in their abilities, and identifying themselves with their organization. Accordingly, hypothesis two would be proposed as follows:

H2: Psychological ownership positively affects employees' intrapreneurship behavior.

\section{3-3 Achievement Motivation and Intrapreneurship}

Recent studies have been interested in studying the role of motivation in explaining the increase in employees' intrapreneurship behavior. 
They have revealed that intrapreneur's motivation (Nessen, et al., 2019; Sadeghpour, et al, 2019), personal motivators (Badoiu et al, 2020), and self motivation (Marques; Marques; Ferreira and Ferreira, 2019) tend to increase intrapreneurship behavior.

Moreover, in another vein of qualitative research, Ali and his colleagues (2020) revealed that managers working in Malaysian organizations would do not have to punish employees attempting to innovate and change the situation, they would rather motivate them developing their innovative behavior. In another qualitative study, exhibited in the public sector, Ntoyanto-Tyatyantsi (2018) observed that most of the respondents noted that they work in a rigid environment, which has a negative effect on creativity and innovation. The results also indicated that motivation is one of the most significant intrapreneurship enablers noted by those participants.

Notably, from the above discussion, it was recorded that prior field and qualitative research have mainly focused on the relationships between self motivation and motivational factors, and employees' intrapreneurship behavior (e. g. Ali, et al., 2020; Marques, et al., 2019). Interestingly though, according to the current researchers' review in the literature, few studies have investigated the role of achievement motivation in enhacing intrapreneurship intentions.

On the one hand, Shaikh and her colleagues (2019) explained the significant role of achievement motivation, that is, when the intrapreneur has a high need for achieving his work, he may then go beyond his old role as only an employee, and may also explore new opportunities and introduce innovation practices to offer customers new services. Their results revealed that achievement motivation plays the predictor role of intrapreneurship intentions. Interestingly, on the other hand, Razavi and Ab Aziz (2017) failed to find such relationship in Iran.

Hence, it could be argued that although both research (Razavi and Ab Aziz 2017; Shaikh, et al., 2019) were interested in investigating the achievement motivation-intrapreneurship intentions relationship, rather than employees' intrapreneurship behavior. Additionally, only Shaikh and her colleagues (2019) have revealed this relationship, while 
Razavi and Ab Aziz (2017) have not. Therefore, due to those diverse results, the current research would propose that the role of achievement motivation in explaining the variance in employees' intrapreneurship behavior is still underresearched and needs more investigation.

Accordingly, relying on the McClelland's learned needs theory (1965), and agreeing with Shaikh and her colleagues' results (2019), the current research would suggest that employees trying to improve their performances, achieving difficult organizational goals and satisfied with accomplishing difficult missions will exhibit more intrapreneurship behaviors. Therefore, the study would hypothesize the following:

H3: Achievement motivation positively affects employees' intrapreneurship behavior.

\section{3-4 Personality and Intrapreneurship}

Regarding the personality traits-intrapreneurship behavior relationships, many researchers have claimed that the big five dimensions affect employees' intrapreneurship behavior, either positively, or negatively (Alam et al, 2020; Farrukh, et al, 2016; Woo, 2018).

By reviewing the literature, it was noted that researchers differ in their claims regarding these positive or negative relationships. For example, both studies of Farrukh and his colleagues (2016), and Rodrigues and Rebelo (2019) have recorded positive relationships between emotional stability, extraversion and openness to experience, and intrapreneurship behavior. Meanwhile, a negative relationship was recorded between agreeableness and intrapreneurship behavior (Farrukh, et al, 2016), whereas a non-significant effect of agreeableness on innovative performance was also recorded (Rodrigues and Rebelo, 2019).

The main reasons for these different claims and results are that extroverts, emotionally stable and openned to experience individuals do not fear challenges, they also do not avoid problems, and are motivated to implement novel ideas and find novel opportunities. While, agreeable individuals are more interested in others' feelings, 
help and cooperate with other people, and avoid being belligerent to others. Hence, they would have some difficulties in expressing and generating novel ideas, different from other individuals (Farrukh, et al, 2016).

In agreement with these prior research, other scholars revealed positive effects of both extraversion and openness to experience on individual intrapreneurship behavior (Alam, et al., 2020; de Vries; Wawoe and Holtrop, 2016; Woo, 2018), and on risk propensity (Sinha and Srivastava, 2013). Extraversion was also found to have positive effects on both innovative behavior, and innovative implementation behavior (Duradoni and Di Fabio, 2019 a), in addition to intrapreneurial self-capital (Duradoni and Di Fabio, 2019 b). Additionally, emotionality and sociability were also recorded to have significant positive effects on intrapreneurial self-capital (Di Fabio and Saklofske, 2019).

As per the the conscientiousness-intrapreneurship behavior relationship, prior findings showed that this relationship is in some way confusing. In this regard, two main arguments were presented and supported by some studies: on the one hand, conscientious persons who are highly task performers, and are more satisfied with their jobs, are found to be less motivated in finding novel opportunities, they avoid risk taking, and are being afraid of causing delays in their jobs (Farrukh, et al, 2016). On the other hand, and as a second perspective, other conscientious persons who are motivated and orientated by goals, are found to be more engaged in intrapreneurship careers than traditional ways of work (Alam, et al., 2020; de Vries et al., 2016; Rodrigues and Rebelo, 2019; Sinha and Srivastava, 2013; Woo, 2018).

On the other hand, some recent veins of research were interested in studying some other personality characteristics. In this context, Monfared and his colleagues (2019) have found that personality chraracteristics, including ethical behavior, listening, coordination, motivationg others for innovating, empathy, communication, hope for success, prospecting, persistence, and performing extra work are directly related to intrapreneurship behavior. Sadeghpour and his colleagues (2019) have also found that human factors and personality characteristics affect organizational entrepreneurship. Furtheremore, 
Shaikh and her colleagues (2019) have added that personality traits and characterstics, including problem-solving are predictors of intrapreneurship intentions.

To sum up, although researchers have proved the significant big five traits-employees' intrapreneurship behaviors relationships, interestingly though, some contradictory findings were noted. Hence, due to these conflicting findings, and inconclusive results, those debatable relationships would be also a subject of this research. Convinced that extrovert, emotionally stable, openned to experience and conscientious people will be more involved in intrapreneurship behavior; whereas agreeable people will be less involved in these behaviors, two main hypotheses would be elaborated as follows:

H4: Extraversion, emotional stability, conscientiousness, and openness to experience positively affect employees' intrapreneurship behavior.

H5: Agreeableness negatively affect employees' intrapreneurship behavior.

So far, the above discussion has introduced some organizational and individual antecedents for enhancing employees' intrapreneurship behavior. The current research would then suggest that those straightforward relationships may be also conditioned on some favorable situations. And thus, introduces transformational leadership as a moderating variable as follows:

\section{3-5 The Moderating Role of Transformational Leadership}

In addition to all of the above-mentioned variables affecting employees' intrapreneurship behavior, managerial support was found to be an essential factor in encouraging these behaviors (Badoiu, et al., 2020; Moriano et al., 2014; Nessen, et al., 2019; Walberg, 2019). Managers also play a great role in creating an enabling environment for intrapreneurship, recruiting, trainning, rewarding and keeping talented, innovative people; where the proper ideas of employees are welcomed and supported (Buekensa, 2014).

In this regard, transformational leaders are percieved as having influence, inspiration, motivation, and humanistic orientation. They also concentrate on the needs of the future and focus on the long-term 
concerns and issues (Avolio and Bass, 2002; Bass, 2000). Moreover, transformational leaders stimulate and boost innovative activities and thinking. They also create an innovative work climate for the acquisition of knowledge and technology inside the organizations (Khan; Aslam and Riaz, 2012). Additionally, they encourage employees to investigate novel opportunities, introduce new products or accelerate work processes and procedures (Moriano, et al., 2014).

Notably, by reviewing the literature review, it was found that most of the recent studies have specifically investigated the role of transformational leadership as an important Leadership type in encouraging employees' intrapreneurship behavior either directly or indirectly (Farrukh, et al., 2019; Watts, et al., 2020).

Additionally, in another stream of research, applied in some transition economies, and depending on the full range theory of leadership (Avolio and Bass, 2002), scholars have also agreed that transformational leadership is a positive predictor of intrapreneurship behavior either directly or indirectly in Pakistanian organizations (Khan, et al., 2012, 2020; Shafique and Kalyar, 2018), in Tunisian SME's (Boukamcha, 2019) and in Kurdistan (Rastbin, 2016).

Obviously, it can be concluded that these main streams of research were interested in studying the direct and indirect role of transformational leadership in enhancing employees' intrapreneurship behavior either in developed or transition economies. It was also noted the lack of studying its moderating role on the individual and organizational determinants-employees' intrapreneurship behavior relationships.

To support this claim, and depending on the researchers' review in the literature, it was noted that only (Razavi and Ab Aziz, 2017) revealed the moderating role of transformational leadership on the relationship between each of proactivenss, risk-taking, and innovativeness and intrapreneurship intentions. But did not play the same moderating role between networking and need for achievement and intrapreneurship intentions.

From the avove discussion, the current study may conclude that although the role of transformational leadership in stimulating and 
facilitating employees' intrapreneurship behavior has been extensively studied as elaborated previously, though (Razavi and Ab Aziz study, 2017) was the one that has been interested in studying its moderating role, and revealed different results. To capture this gap, the present study would argue that there is a great need to examine the interactive role of transformational leadership with the proposed organizational and individual determinants on the one side, and employees' intrapreneurship behavior on the other side. Therefore, it hypothesizes the following:

H6: Transformational leadership moderates the relationships between organizational climate for psychological safety, psychological ownership, achievement motivation and personality traits on the one hand, and employees' intrapreneurship behavior on the other hand.

The following figure represents the study's model, designed to test the research relationships in interest: 


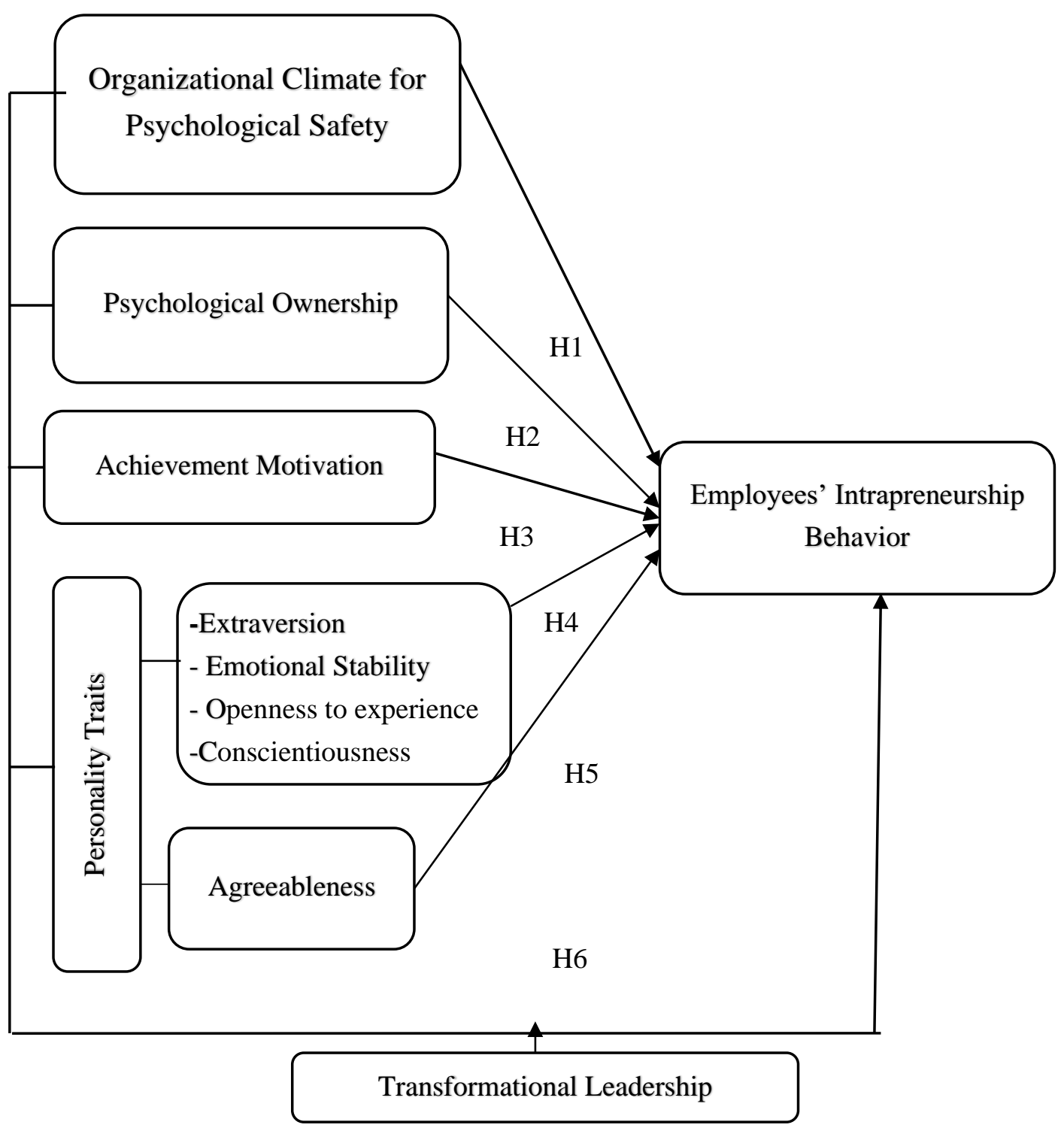

Figure 1: Model of the Study

\section{4- Research Methodology}

\section{4-1 Pilot Study}

In an earlier phase of this research, a pilot study was conducted with some employees working in several private and governmental institutions in Alexandria. Respondents were approached while attending their EMBA programs. Semi-structured interviews were employed with 26 students in Alexandria University, and 17 students in Eslsca University during the spring semester 2020. Interviews were 
conducted both individually and as groups, to capture participants' responses about the availability, antecedents, and the main conditions enabling the intrapreneurship phenomenon in the Egyptian context.

The majority of respondents stated that intrapreneurship behaviors are most likely excercised in private organizations, while hardly present in the Egyptian governmental sectors. This was due to the rigid rules and procedures that may inhibit practicing these behaviors. They have also declared that among many other variables, enabling a safe and healthy environment is crucial for helping them innovate, being proactive, and taking some risk. They have also revealed that some individual factors are of a great importance for encouraging those behaviors, such as feeling a sense of belongingness to the organization as their place, in which they identify themselves with, and believe in their capabilities achieving their jobs. Additionally, when they are motivated to accomplish some difficult missions, and have some personal characteristics. They have also stressed on the favorable conditions enabling high levels of employees' intrapreneurship behaviors, such as effective leadership.

\section{4-2 Data Collection Methods}

A field research using a self-administered questionnaire was conducted to collect primary data. The questionnaire consists of seven main parts: the first six parts include questions reflecting the main research variables, while the seventh reflects respondents' personal information.

\section{4-3 Research Sampling}

A convenient sampling technique was used for collecting data. This procedure was taken due to the Covid 19 closings, and the lack of getting complete sampling frames during the pendemic. Referring to the pilot study results, only private sector employees working in different activities in Alexandria were included, rather than employees working in public sector ones. Data was collected using both on-line questionnaires, in addition to 400 questionnaires that were distributed in some private commercial, industrial, and service organizations. Some referent persons working in those different sectors have helped researchers reaching the sampled respondents and collecting data during the closing conditions. The total returned and valid 
questionnaires reached a number of 495: of which 173 were returned from the on-line questionnaires, while 322 were obtained from the distributed questionnaires. Table (1) exhibits the respondents' profile as follows:

Table 1: Respondents Profile

\begin{tabular}{|l|c|c|}
\hline \multicolumn{1}{|c|}{ Respondents Profile } & Frequency & Percentage \\
\hline Age & & \\
\hline Less than 30 & 190 & 38.4 \\
\hline 30-Less than 40 & 183 & 37.0 \\
\hline 40 -Less than 50 & 106 & 21.4 \\
\hline 50 and more & 15 & 3.0 \\
\hline Missing Value & 1 & 0.2 \\
\hline Total & 495 & 100.0 \\
\hline Gender & & \\
\hline Male & 350 & 71 \\
\hline Female & 143 & 28.9 \\
\hline Missing Value & 2 & 0.004 \\
\hline Total & 495 & 100.0 \\
\hline Administrative Level & 64 & \\
\hline Top Management & 216 & 43.9 \\
\hline Middle Management & 214 & 43.2 \\
\hline First Line & 1 & 0.202 \\
\hline Missing Value & 495 & 100.0 \\
\hline Total &
\end{tabular}

As shown in table (1), the results indicated that most of the respondents are below 40 years old, where $38.4 \%$ are below 30 $(n=190)$, and $37 \%$ are within the $30->40$ category $(n=183)$. Male respondents represent almost $71 \%$ of the sample $(n=350)$, whereas female respondents accounted for almost $30 \%$ of the sample $(n=143)$. Additionally, most of the respondents lie in the middle $(n=216$, and accounted for almost $44 \%$ of the sample size), and first line levels ( $n=214$, and accounted for almost $43 \%$ of the sample size).

\section{4-4 Measures}

4-4-1 The Organizational Variable: Organizational Climate for Psychological Safety

The team psychological safety scale was first developed by Edmondson (1999). The scale was then adapted by (Baer and Frese, 2003), to be used at the organizational level. They have referred to this 
organizational climate as the formal and informal practices of management in the organization, it is also the support and trust in an open environment. The current research has used the scale adapted by Baer and Frese, which consists of 7 statements. Statements 1, 2 and 4 are inverse statements. The scale was rated on a five-point scale, ranging from 1 (completely disagree) to 5 (completely agree).

\section{4-4-2Individual Variables}

\section{4-4-2-1 Psychological Ownership}

Psychological ownership to an object is referred to as the possessing feeling that this object or target is considered as "mine" or as "ours" (Pierce, et al., 2001; Van Dyne and Pierce, 2004). Avey and his colleagues (2009) have developed the Psychological Ownership Questionnaire (POQ). It includes 16 statements, and was rated on a sixpoint scale, ranging from 1 (strongly disagree) to 6 (strongly agree). The current researchers have got a permission to use the questionnaire published by Mind Garden Inc. It was then translated by the researchers and approved by the owners.

The POQ assesses two distinct theoretically forms: promotivation and preventative. The preventative psychological ownership, named as territoriality, refers to the employees who feel a sense of ownership over something, and would be territorial over it, such as resources and information. Therefore, they feel themselves the ones who should decide how to use or deal with it (questions 1-4). The promotivation psychological ownership, consists of four distinct dimensions: the selfefficacy dimension, referred to as confidence, in which the person believes in his own ability for achieving tasks and missions (questions 5-7) The accountability dimension, referred to as the individual's feeling of responsibility towards keeping other individuals and organizations more accountable for the target of ownership (questions 8-10). In addition to the sense of belongingness, regarded to as the sense of place, and determines the degree to which the individual feels like being at home in his work place, and that he belongs to the organization (questions 11-13). Finally, the sense of self-identify, meaning that when the individual is at the highest level of psychological 
ownership, he will identify himself with his organization, and tends to give more attention to it (questions 14-16).

\section{4-4-2-2 Achievement Motivation}

Achievement motivation was measured using (McClelland's scale, 1965). The scale consists of 5 statements, and was rated on a five-point scale, ranging from 1 (completely disagree) to 5 (completely agree).

\section{4-4-2-3 Personality Traits}

Extraversion (sociability), agreeableness, emotional stability (adjustment), conscientiousness and openness to experience are the main big five dimensions of personality, namely: the five factor model (Farrukh, et al, 2016; Goldberg, 1990; John and Srivastava, 1999). The big five traits were measured using a short version developed by Shani, Chandler, Coget and Lau (2009). It consists of 25 statements, measured on a numerical scale ranging from 1 to 5 , to point the trait that most describes respondents' personality. The mid point (3) indicates that the term equally describes respondents' trait.

The adjustment or emotional stability dimension was referred to as the degree to which persons are calm, self confident and not neurotic (questions 1, 6, 11, 16 and 21). The sociability or extraversion dimension was regarded as the degree to which persons are talkative, energetic, assertive, ambitious, and enthusiastic (questions number 2, 7, 12, 17 and 22). The openness dimension was regarded as the extent to which persons are broad minded, intellectual, and imaginative (questions 3, 8, 13, 18 and 23). Additionally, the agreeableness dimension, was referred to as the degree to which persons are cooperative, courteous, trusting, and tolerant (questions 4, 9, 14, 19 and 24). Finally, the conscientiousness dimension, was referred to as the extent to which persons are hard workers, self disciplined, dependable, and responsible (questions 5, 10, 15, 20 and 25).

\section{4-4-2-4 The Dependent Variable: Employees' Intrapreneurship Behavior}

Employees' intrapreneurship behavior is regarded to as the process by which employees explore and respond to new opportunities, by practicing innovativeness, proactiveness and by taking some risks. This will help the organization creating novel products, services, and 
processes, it will also help initiating self renewal or novel businesses, to increase organizational competitiveness and performance (Nessen and his colleagues, 2019).

It includes three main dimensions: proactiveness, which is the prediction, anticipation, and actions to meet the future needs, modifications and changes which will lead to novel opportunities. Risktaking, which is the tendency and propensity of employees to take risks intending to benefit the organization. And lastly, innovativeness, which is the tendency and propensity of employees to invent and create novel ideas (Moriano et al., 2014; Valsania, et al., 2016).

González-Serrano, Moreno, Valantine and Hervás (2019) have developed a scale to measure the intrapreneurship intentions. This scale was based on the intrapreneuship behavior scale of (Stull and Singh, 2005). It consists of 7 items reflecting two dimensions: the innovativeness (questions 1-4), and risk-taking dimensions (questions 5-7). The current researchers have made some slight changes in wording, to reflect the intrapreneurship behavior. Hence, wording was changed from "I would", to the present tense to reflect employees' intrapreneurship behavior, rather than their intentions. Additionally, Kanten and Alparslan's scale (2013) was used to measure the proactiveness dimension, consisting of 6 items (questions 8-13). The scale was rated on a five- point scale, ranging from 1 (completely disagree) to 5 (completely agree).

\section{4-4-2-5 The Moderating Variable: Transformational Leadership}

Transformational leadership refers to that type of leader who inspires his followers to implement the organization' vision and aims at achieving collective goals. Dimensions of transformational leadership have been identified as idealized influence, inspirational motivation, intellectual stimulation, and individualized consideration (Avolio and Bass, 2002). It was measured using the scale developed by Avolio and Bass (2002). The scale's wording was very slightly changed to begin statements with "the leader" instead of "I". It consists of 12 statements, and was rated on a five-point scale, ranging from 1 (completely disagree) to 5 (completely agree). The idealized influence refers to the leader who tends to put his subordinates' needs before his own needs, 
when feeling respected and trusted by those subordinates (questions 13 ). The inspirational motivation, referring to the leader who is acting in a way that makes subordinates perform well, by creating a meaning sense of their work (questions 4-6). Moreover, the intellectual stimulation, which means that the leader is asking and encouraging his subordinates to enhance and increase creativity and innovation (questions 7-9). Finally, the individualized consideration, meaning that the leader is perceived as a coach or a mentor from his subordinates (questions 10-12).

\section{4-4-2-6 Demographic Variables}

Three main demographic variables have been included in the questionnaire: respondents' age, gender, and administrative level.

\section{4-5 Data Analysis}

\section{4-5-1 Data Analysis Methods}

Research data has been analysed using the statistical package of SPSSversion 23. Hierarchical regression analysis was conducted to test the

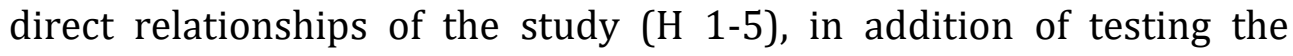
interactive relationships (H6). Furtheremore, factor analysis, using the varimax technique was employed to determine item factor loadings, and average variances of the research variables.

\section{4-5-2 Validity, Reliability and Descriptive Statistics}

Different validity and reliability tests were applied. Reliability is regarded to as the degree of consistency between items of one construct, while validity is referred to as the degree of measuring the items of a certain construct in the right way (Sekaran and Bougie, 2016). Content validity was assessed, in which measures of the study were evaluated by some HR professors in Alexandria University, to assure that the reserarch measures fully represent the studied variables.

The construct validity of the study measures was also proved, where both of convergent and discriminant validity have been measured. Convergent validity was assessed, where the Average Variance Extracted (AVE) was computed, AVE values are adequate when they are equal or greater than $50 \%$. Additionally, all the factor Loadings (FL) 
should be equal or greater than 0.5. After deleting low factor loadings items, it was recorded that AVE and FL values are within the accepted levels. Reliability was also revealed using Cronbach Alpha (Cronbach, 1951), where all the values are within the acceptable levels. Convergent validity and reliability results are exhibited in table (2) as follows:

Table 2: Convergent Validity and Reliability of the Study Variables

\begin{tabular}{|c|c|c|c|c|c|}
\hline Variables & $\begin{array}{c}\text { Cronbach's } \\
\text { Alpha }\end{array}$ & AVE & $\sqrt{A V E}$ & Items & FL \\
\hline $\begin{array}{l}\text { Organizational Climate } \\
\text { for Psychological Safety }\end{array}$ & 0.792 & 0.61656 & 0.785 & $\begin{array}{l}3 \\
5 \\
6 \\
7\end{array}$ & $\begin{array}{l}0.772 \\
0.813 \\
0.789 \\
0.766\end{array}$ \\
\hline $\begin{array}{l}\text { Psychological } \\
\text { Ownership }\end{array}$ & 0.893 & 0.6548 & 0.81 & $\begin{array}{c}1 \\
2 \\
3 \\
4 \\
5 \\
6 \\
7 \\
8 \\
9 \\
10 \\
11 \\
12 \\
13 \\
14 \\
15 \\
16\end{array}$ & $\begin{array}{l}0.615 \\
0.765 \\
0.794 \\
0.793 \\
0.852 \\
0.829 \\
0.757 \\
0.565 \\
0.663 \\
0.521 \\
0.762 \\
0.852 \\
0.837 \\
0.773 \\
0.837 \\
0.680\end{array}$ \\
\hline $\begin{array}{l}\text { Achievement } \\
\text { Motivation }\end{array}$ & 0.904 & 0.7278 & 0.853 & $\begin{array}{l}1 \\
2 \\
3 \\
4 \\
5\end{array}$ & $\begin{array}{l}0.814 \\
0.866 \\
0.865 \\
0.841 \\
0.878\end{array}$ \\
\hline Personality Traits & 0.96 & $\begin{array}{ll}--- \\
\end{array}$ & $-\cdots$ & $\begin{array}{ll}--- \\
\end{array}$ & $\begin{array}{ll}--- \\
\end{array}$ \\
\hline Extraversion & 0.688 & 0.51783 & 0.720 & $\begin{array}{c}2 \\
12 \\
17 \\
22 \\
\end{array}$ & $\begin{array}{l}0.687 \\
0.733 \\
0.760 \\
0.696\end{array}$ \\
\hline Emotional Stability & 0.719 & 0.78093 & 0.825 & $\begin{array}{l}11 \\
21 \\
\end{array}$ & $\begin{array}{l}0.884 \\
0.884 \\
\end{array}$ \\
\hline $\begin{array}{l}\text { Openness to } \\
\text { Experience }\end{array}$ & 0.652 & 0.55125 & 0.742 & $\begin{array}{c}3 \\
13 \\
18 \\
23 \\
\end{array}$ & $\begin{array}{l}0.648 \\
0.777 \\
0.801 \\
0.735\end{array}$ \\
\hline
\end{tabular}




\begin{tabular}{|c|c|c|c|c|c|}
\hline Conscientiousness & 0.71 & 0.53316 & 0.73 & $\begin{array}{c}5 \\
15 \\
20 \\
25\end{array}$ & $\begin{array}{l}0.757 \\
0.690 \\
0.708 \\
0.763\end{array}$ \\
\hline Agreeableness & 0.712 & 0.63569 & 0.80 & $\begin{array}{c}4 \\
9 \\
14 \\
\end{array}$ & $\begin{array}{l}0.756 \\
0.826 \\
0.808 \\
\end{array}$ \\
\hline $\begin{array}{l}\text { Transformational } \\
\text { Leadership }\end{array}$ & 0.960 & 0.69815 & 0.836 & $\begin{array}{c}1 \\
2 \\
3 \\
4 \\
5 \\
6 \\
7 \\
8 \\
9 \\
10 \\
11 \\
12 \\
\end{array}$ & $\begin{array}{l}0.773 \\
0.862 \\
0.857 \\
0.862 \\
0.877 \\
0.869 \\
0.846 \\
0.849 \\
0.824 \\
0.875 \\
0.772 \\
0.776 \\
\end{array}$ \\
\hline $\begin{array}{l}\text { Intrapreneurship } \\
\text { Behaviors }\end{array}$ & 0.922 & 0.60978 & 0.78 & $\begin{array}{c}1 \\
2 \\
3 \\
4 \\
5 \\
6 \\
7 \\
8 \\
9 \\
10 \\
11 \\
12 \\
13\end{array}$ & $\begin{array}{l}0.775 \\
0.814 \\
0.779 \\
0.796 \\
0.663 \\
0.624 \\
0.637 \\
0.765 \\
0.779 \\
0.754 \\
0.643 \\
0.629 \\
0.711\end{array}$ \\
\hline
\end{tabular}

Table (3) shows descriptive statistics. Means and standard deviations values cleared that the variables' means are between 2.79 to 4.54 , while standard deviation scores are within 0.808 to 1.127 . By looking closely to the above-mentioned results, it was recorded that the variables means are within the average scores. Furtheremore, psychological ownership variable came with the highest mean, whereas emotional stability recorded for the lowest mean.

Discriminant validity was also measured, to avoid the common method variance (CMV) problem. Table (3) shows the adequate discriminant validity. The results indicated that all the square roots of the average 
value extracted for each construct were greater than its correlation with other consructs (Fornell \& Larcker, 1981).

Table 3: Descriptive Statistics

\begin{tabular}{|c|c|c|c|c|c|c|c|c|c|c|c|c|}
\hline & $\begin{array}{l}3 \\
0 \\
5\end{array}$ & 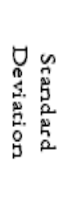 & 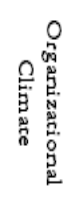 & 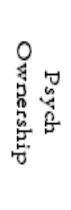 & 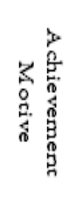 & 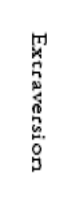 & 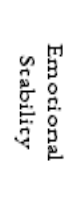 & 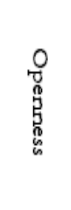 & 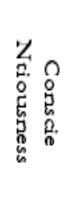 & 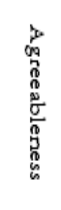 & 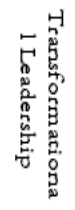 & 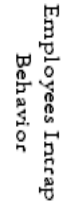 \\
\hline Organizational Climate & 3.417 & 1.039 & $(0.785)$ & & & & & & & & & \\
\hline Psych Ownership & 4.546 & 0.977 & 0.386 & $(0.81)$ & & & & & & & & \\
\hline Adhievement Motive & 4.266 & 0.896 & $0.225^{\prime}$ & $0.533^{\circ}$ & $(0.853)$ & & & & & & & \\
\hline Extraversion & 3.434 & 0.976 & 0.197 & 0.146 & 0.043 & $(0.72)$ & & & & & & \\
\hline Emotional Stability & 2.792 & 1.127 & .071 & $0.215^{\circ}$ & $0.327^{\prime}$ & $-0.295^{\circ}$ & $(0.825)$ & & & & & \\
\hline Openness & 2.964 & 1.045 & $0.107^{\prime}$ & $-0.157^{\circ}$ & $-0.241^{\prime}$ & $0.398^{\prime}$ & $-0.639^{\circ}$ & $(0.742)$ & & & & \\
\hline Conscientiousness & 4.041 & 0.837 & $0.16 i^{\circ}$ & $0.317^{\prime}$ & $0.325^{\prime}$ & $0.177^{\circ}$ & $0.208^{\prime}$ & $-0.113^{\prime}$ & $(0.73)$ & & & \\
\hline Agreeableness & 4.046 & 0.930 & 0.059 & $0.271^{\prime}$ & $0.322^{\prime}$ & 0.114 & 0.296 & $-0.091^{\prime}$ & $0.503^{\circ}$ & $(0.80)$ & & \\
\hline $\begin{array}{c}\text { Transformational } \\
\text { Leadership }\end{array}$ & 3.750 & 1.040 & 0.539 & $0.508^{\circ}$ & 0.347 & $0.265^{\circ}$ & -0.001 & 0.035 & $0.178^{\circ}$ & 0.087 & $(0.836)$ & \\
\hline $\begin{array}{c}\text { Employees Intrap } \\
\text { Behavior }\end{array}$ & 3.941 & 0.808 & 0.324 & $0.665^{\circ}$ & $0.602^{\prime}$ & $0.105^{\prime}$ & $0.238^{\prime}$ & -0.125 & $0.368^{\prime}$ & $0.275^{\circ}$ & $\begin{array}{l}\text { Act } \\
0.439 \\
60 t\end{array}$ & $\left(\begin{array}{l}\text { ate } \\
0.78) \\
5 e t t i n\end{array}\right.$ \\
\hline
\end{tabular}

*Correlation is significant at the 0.05 level (2-tailed).

\section{4-6 Results and Hypotheses Testing}

As mentioned before, hierarchical regression analysis was employed, where simple relationships were first regressed for each of the study antecedents on the dependent variable (H1-5). TL was then regressed as an independent variable with each of the independent factors on the dependent variable. And lastly, moderating relationships were then regressed to investigate the interactive role of TL with each of the independent variables on the dependent variable (H6).

For organizing and simplifying the presentation of the study results, the first step of the hierarchical analysis will be presented separately. Therefore, simple regression findings, reflecting the direct relationships (H1-5) will be first cleared in table (4). Then, the other two phases, reflecting incorporating $\mathrm{TL}$ as an independent variable, and the 
interactive role of TL on each of the above direct relationships will be presented in tables 5-12.

Table (4) shows the findings of the direct organizational and individual determinants-employees' intrapreneurship behaviors relationships as follows:

Table 4: (H1-5) Results

\begin{tabular}{|l|c|c|c|c|c|c|}
\hline \multicolumn{7}{|c|}{ Employees' Intapreneurship Behaviors } \\
\hline & $\mathbf{B}$ & $\begin{array}{c}\mathbf{T} \\
\text { value }\end{array}$ & $\mathbf{p}$ - value & $\mathbf{R}^{\mathbf{2}}$ & $\begin{array}{c}\mathbf{F} \\
\text { Value }\end{array}$ & $\begin{array}{c}\text { Model } \\
\text { Fit } \\
\text { “Sig” }\end{array}$ \\
\hline $\begin{array}{l}\text { Organizational Climate } \\
\text { for Psychological } \\
\text { Safety }\end{array}$ & 0.252 & 7.602 & 0.001 & $0.10^{*}$ & 57.787 & 0.001 \\
\hline $\begin{array}{l}\text { Psychological } \\
\text { Ownership }\end{array}$ & 0.55 & 19.764 & 0.001 & $0.44^{*}$ & 390.624 & 0.001 \\
\hline $\begin{array}{l}\text { Achievement } \\
\text { Motivation }\end{array}$ & 0.544 & 16.754 & 0.001 & $0.36^{*}$ & 280.686 & 0.001 \\
\hline Extraversion & 0.087 & 2.352 & 0.019 & $0.011^{*}$ & 5.534 & 0.019 \\
\hline Emotional Stability & 0.171 & 5.430 & 0.001 & $0.056^{*}$ & 29.488 & 0.001 \\
\hline Openness & -0.096 & -2.787 & 0.006 & $0.016^{*}$ & 7.769 & 0.006 \\
\hline Conscientiousness & 0.356 & 8.792 & 0.001 & $0.136^{*}$ & 77.293 & 0.001 \\
\hline Agreeableness & 0.239 & 6.355 & 0.001 & $0.076^{*}$ & 40.384 & 0.001 \\
\hline
\end{tabular}

* Correlation is significant at 0.05 level (2-tailed)

As indicated in table (4), findings came to support H1, 2 and 3. The results revealed significant positive effects of organizational climate for psychological safety (H1), psychological ownership (H2), and achievement motivation (H3) on employees' intrapreneurship behaviors.

The findings have also revealed beta coefficient values equal to 0.252 (H1), 0.55 (H2), 0.544 (H3). Meaning that an increase of one standard unit for each of the three variables, will then be reflected in an increase of $0.252,0.55$, and 0.544 in employees' intrapreneurship behaviors consequtively. $\mathrm{R}^{2}$ values rated for $0.10,0.44$ and 0.36 respectively, indicating that organizational climate for psychological safety, psychological ownership, and achievement motivation explained 10\%, $44 \%$ and $36 \%$ of the total variance in employees' intrapreneurship behavior. All the above relationships are significant at 0.05 level ( $p$ value $=0.001$ ). Therefore, accepting the first three hypotheses. 
H4: suggested that each of extraversion, emotional stability, conscientiousness, and openness to experience have positive effects on employees' intrapreneurship behavior. The results presented in table (4) showed mixed findings, indicating a partial acceptance for H4. The findings cleared that extraversion (beta $=0.087, \mathrm{R}^{2}=0.011, \mathrm{P}=0.019$ ), emotional stability (beta $=0.171, \quad \mathrm{R}^{2}=0.056, \quad \mathrm{P}=0.001$ ) and conscientiousness (beta $=0.356, \mathrm{R}^{2}=0.136, \mathrm{P}=0.001$ ) positively affect employees' intrapreneurship behaviors. Whereas a negative effect of openness to experience on employees' intrapreneurship behaviors was recorded (beta=-0.096, $\mathrm{R}^{2}=0.016, \mathrm{P}=0.006$ ).

H5 proposed that agreeableness has a negative effect on employees' intrapreneurship behavior. The findings revealed in table (4) did not support this research claim, indicating a significant positive relationship (beta $=0.239, \mathrm{R}^{2}=0.076$, sig at 0.05 level and $(\mathrm{p}$ value= 0.001). Hence, rejecting $H 5$.

H6 proposed that transformational leadership plays the moderating role in the above direct relationships. The results have also revealed mixed findings, therefore accepting $\mathrm{H} 6$ partially. These interactive results are shown in tables 5-12 as follows:

Table 5: Moderated Regression Analysis Results

(Organizational Climate for Psychological Safety)

\begin{tabular}{|c|c|c|c|c|c|c|}
\hline \multirow[b]{2}{*}{ Variable } & \multicolumn{3}{|c|}{ Model 1} & \multicolumn{3}{|c|}{ Model 2} \\
\hline & B & T value & $\begin{array}{c}\text { p- } \\
\text { value }\end{array}$ & B & T value & $\begin{array}{c}\text { p- } \\
\text { value }\end{array}$ \\
\hline $\begin{array}{l}\text { Organizational } \\
\text { Climate }\end{array}$ & 0.095 & 2.565 & 0.011 & -0.181 & -1.730 & 0.083 \\
\hline TL & 0.290 & 7.816 & 0.001 & 0.076 & 0.909 & 0.364 \\
\hline Climate*TL & - & - & - & 0.075 & 2.8307 & 0.005 \\
\hline $\mathrm{R}^{2}$ & \multicolumn{3}{|c|}{$\mathrm{R}^{2}=0.204^{*}, \mathrm{~F}=62.963, \mathrm{P}=0.001$} & \multicolumn{3}{|c|}{$\mathrm{R}^{2}=0.217^{*}, \mathrm{~F}=45.26 \mathrm{P}=0.001$} \\
\hline$\Delta \mathrm{R}^{2}$ & & & & \multicolumn{3}{|c|}{$\Delta \mathrm{R}^{2}=0.013^{*}, \mathrm{~F}=8.050 \mathrm{P}=0.005$} \\
\hline
\end{tabular}

* Correlation is significant at 0.05 level (2-tailed)

The results shown in table (5) cleared the role of organizational climate for psychological safety and TL as independent variables on the dependent variable (model 1). In addition to the role of TL as an interactive variable on the relationship between organizational climate for psychology safety and intrapreneurship behaviors (model 2). Obviously, the relationship between the organizational climate and the 
dependent variable was positive, yet the inclusion of TL as an interactive variable has turned this positive relationship into a nonsignificant negative one $(\mathrm{P}=0.083)$. The results also revealed that transformational leadership plays the interactive role with the organizational climate for psychological safety in explaining the variance in intrapreneurship behaviors, with a significant increase of $1.3 \%(\mathrm{P}=0.005)$.

Table 6: Moderated Regression Analysis Results (Psychological Ownership)

\begin{tabular}{|l|c|c|c|c|c|c|}
\hline \multirow{2}{*}{ Variable } & \multicolumn{3}{|c|}{ Model 1 } & \multicolumn{3}{c|}{ Model 2 } \\
\cline { 2 - 7 } & B & T value & $\begin{array}{c}\text { p- } \\
\text { value }\end{array}$ & B & $\begin{array}{c}\text { T } \\
\text { value }\end{array}$ & $\begin{array}{c}\text { p- } \\
\text { value }\end{array}$ \\
\hline $\begin{array}{l}\text { Psychological } \\
\text { Ownership }\end{array}$ & 0.492 & 15.418 & 0.001 & 0.544 & 7.671 & 0.001 \\
\hline TL & 0.106 & 3.547 & 0.001 & 0.179 & 1.90 & 0.058 \\
\hline Ownership*TL & - & - & - & -0.16 & -0.810 & 0.419 \\
\hline $\mathrm{R}^{2}$ & \multicolumn{3}{|l|}{$\mathrm{R}^{2}=0.456^{*}, \mathrm{~F}=206.186, \mathrm{P}=0.001$} & \multicolumn{2}{|c|}{$\mathrm{R}^{2}=0.457^{*}, \mathrm{~F}=0.137, \mathrm{P}=0.001$} \\
\hline$\Delta \mathrm{R}^{2}$ & \multicolumn{4}{|l|}{$\Delta \mathrm{R}^{2}=0.001, \mathrm{~F}=0.656, \mathrm{P}=0.419$} \\
\hline
\end{tabular}

* Correlation is significant at 0.05 level (2-tailed)

Table (6) showed the effect of TL and psychological ownership as independent variables on the dependent variable (model 1). The role of $\mathrm{TL}$ as a moderator on the relationship between psychological ownership and intrapreneurship behavior was not proved (model 2). The result did not support the research claim, in which it revealed no significant role of $\mathrm{TL}$ as a moderator on the above relationship $(\mathrm{P}=0.419)$.

Table 7: Moderated Regression Analysis Results (Achievement Motivation)

\begin{tabular}{|l|c|c|c|c|c|c|}
\hline \multirow{2}{*}{ Variable } & \multicolumn{3}{|c|}{ Model 1 } & \multicolumn{3}{c|}{ Model 2 } \\
\cline { 2 - 7 } & B & T value & $\begin{array}{c}\text { p- } \\
\text { value }\end{array}$ & B & $\begin{array}{c}\text { T } \\
\text { value }\end{array}$ & $\begin{array}{c}\text { p- } \\
\text { value }\end{array}$ \\
\hline Ashievement Motivation & 0.462 & 14.006 & 0.001 & 0.659 & 7.684 & 0.001 \\
\hline TL & 0.204 & 7.175 & 0.001 & 0.487 & 4.161 & 0.001 \\
\hline Achievement*TL & - & - & - & -0.064 & -2.493 & 0.013 \\
\hline $\mathrm{R}^{2}$ & \multicolumn{3}{|l|}{$\mathrm{R}^{2}=0.423^{*}, \mathrm{~F}=180.449, \mathrm{P}=0.001$} & \multicolumn{2}{l}{$\mathrm{R}^{2}=0.43^{*}, \mathrm{~F}=123.647, \mathrm{P}=0.001$} \\
\hline$\Delta \mathrm{R}^{2}$ & \multicolumn{3}{|l}{} & \multicolumn{2}{|c|}{$\Delta \mathrm{R}^{2}=0.007^{*}, \mathrm{~F}=6.217, \mathrm{P}=0.013$} \\
\hline
\end{tabular}

* Correlation is significant at 0.05 level (2-tailed)

The results shown in table (7) cleared the influence of achievement motivation and TL as independents on the dependent variable (model 1). The role of TL as a moderator on the relationship between achievement motivation and intrapreneurship behavior was also 
presented (model 2). A positive relationship between achievement motivation and intrapreneurship behaviors still remains positive in the presence of TL. Though, the results showed a negative interaction between achievement motivation and transformational leadership (beta $=-0.064)$, with a significant increase of $0.007(\mathrm{P}=0.013)$.

Table 8: Moderated Regression Analysis Results (Extraversion)

\begin{tabular}{|l|c|c|c|c|c|c|}
\hline \multirow{2}{*}{ Variable } & \multicolumn{3}{|c|}{ Model 1 } & \multicolumn{3}{c|}{ Model 2 } \\
\cline { 2 - 7 } & B & T value & p- value & B & T value & p-value \\
\hline Extraversion & -0.10 & -0.283 & 0.777 & -0.426 & -10.441 & 0.001 \\
\hline TL & 0.333 & 10.54 & 0.001 & 0.007 & 3.689 & 0.941 \\
\hline Extraversion*TL & - & - & - & 0.110 & 0.074 & 0.001 \\
\hline $\mathrm{R}^{2}$ & $\mathrm{R}^{2}=0.193^{*}, \mathrm{~F}=58.936, \mathrm{P}=0.001$ & $\mathrm{R}^{2}=0.215^{*}, \mathrm{~F}=44.824, \mathrm{P}=0.001$ \\
\hline$\Delta \mathrm{R}^{2}$ & \multicolumn{4}{|c|}{$\Delta \mathrm{R}^{2}=0.022^{*}, \mathrm{~F}=13.609, \mathrm{P}=0.001$} \\
\hline
\end{tabular}

* Correlation is significant at 0.05 level (2-tailed)

Table (8) shows the results of extraversion and TL as independents on the dependent variable (model 1), in addition to the moderating role of TL on the relationship between extraversion and intrapreneurship behavior (model 2). Although that the results of the direct relationship between extraversion and intrapreneurship behavior proved positive (H4), yet the relationship between extraversion and intrapreneurship behavior became negative in the presence of TL as an independent (model 1). This negative relationship remains negative in the presence of the interaction between both variables (model 2). The interaction is significant at the 0.05 level $(\mathrm{P}=0.001)$, with an increase of $2.2 \%$ of the variance in intrapreneurship behavior. This result indicates that TL strengthens the extraversion-intrapreneurship behavior negative relationship.

Table 9: Moderated Regression Analysis Results (Emotional Stability)

\begin{tabular}{|l|c|c|c|c|c|c|}
\hline \multirow{2}{*}{ Variable } & \multicolumn{3}{|c|}{ Model 1 } & \multicolumn{3}{c|}{ Model 2 } \\
\cline { 2 - 7 } & B & T value & p- value & B & T value & p- value \\
\hline Emotional Stability & 0.171 & 6.092 & 0.001 & 0.756 & 6.709 & 0.001 \\
\hline $\mathrm{TL}$ & 0.342 & 11.259 & 0.001 & -0.034 & -0.441 & 0.759 \\
\hline Em Stab*TL & - & - & - & 0.147 & 5.352 & 0.001 \\
\hline $\mathrm{R}^{2}$ & $\mathrm{R}^{2}=0.250^{*}, \mathrm{~F}=81.883, \mathrm{P}=0.001$ & $\mathrm{R}^{2}=0.291^{*}, \mathrm{~F}=67.206, \mathrm{P}=0.001$ \\
\hline$\Delta \mathrm{R}^{2}$ & \multicolumn{9}{|c|}{$\mathrm{R}^{2}=0.041^{*}, \mathrm{~F}=28.648, \mathrm{P}=0.001$} \\
\hline
\end{tabular}

* Correlation is significant at 0.05 level (2-tailed)

Table (9) reveals the findings of emotional stability and TL as independent variables on the dependent variable (model 1), in addition 
to the findings of the moderating role of TL on the relationship between emotional stability and intrapreneurship behavior (model 2). The findings showed that the positive relationship between emotional stability and intrapreneurship behaviors became stronger in the presence of TL. The interaction between both variables is significant at the 0.05 level $(\mathrm{P}=0.001)$, reflecting an increase of $4.1 \%$ of the variance in intrapreneurship behavior.

Table 10: Moderated Regression Analysis Results (Openness to Experience)

\begin{tabular}{|l|c|c|c|c|c|c|}
\hline \multirow{2}{*}{ Variable } & \multicolumn{3}{|c|}{ Model 1 } & \multicolumn{3}{c|}{ Model 2 } \\
\cline { 2 - 7 } & B & T value & $\begin{array}{c}\text { p- } \\
\text { value }\end{array}$ & B & T value & $\begin{array}{c}\text { p- } \\
\text { value }\end{array}$ \\
\hline $\begin{array}{l}\text { Openness to } \\
\text { Experience }\end{array}$ & -0.108 & -3.502 & 0.001 & -0.485 & -4.135 & 0.001 \\
\hline TL & 0.345 & 11.103 & 0.001 & 0.0075 & 0.857 & 0.392 \\
\hline Openness*TL & - & - & - & 0.097 & 3.326 & 0.001 \\
\hline $\mathrm{R}^{2}$ & \multicolumn{3}{|l|}{$\mathrm{R}^{2}=0.213^{*}, \mathrm{~F}=66.486, \mathrm{P}=0.001$} & $\mathrm{R}^{2}=0.230^{*}, \mathrm{~F}=48.917, \mathrm{P}=0.001$ \\
\hline$\Delta \mathrm{R}^{2}$ & \multicolumn{4}{|l|}{} & \multicolumn{2}{l}{$\mathrm{R}^{2}=0.017^{*}, \mathrm{~F}=11.060, \mathrm{P}=0.001$} \\
\hline
\end{tabular}

* Correlation is significant at 0.05 level (2-tailed)

Table (10) shows the results of openness to experience and TL as independent variables (model 1). It also clears the moderating role of TL on the relationship between openness to experience and intrapreneurship behavior (model 2). The results showed that the relationship between openness to experience and intrapreneurship behavior is negative in the presence of TL as an independent variable (model 1). This negative relationship remains negative in the interactive relationship between both variables (model 2). The interaction is also significant at the 0.05 level $(\mathrm{P}=0.001)$, with an increase of $1.7 \%$ of the variance in intrapreneurship behaviors. Meaning that TL plays the moderating role in incresing the openness to experience-intrapreneurship behavior's negative relationship.

Table 11: Moderated Regression Analysis Results (Conscientiousness)

\begin{tabular}{|l|c|c|c|c|c|c|}
\hline \multirow{2}{*}{ Variable } & \multicolumn{3}{|c|}{ Model 1 } & \multicolumn{3}{c|}{ Model 2 } \\
\cline { 2 - 7 } & B & T value & $\begin{array}{c}\text { p- } \\
\text { value }\end{array}$ & B & T value & $\begin{array}{c}\text { p- } \\
\text { value }\end{array}$ \\
\hline Conscientiousness & 0.289 & 7.702 & 0.001 & 0.653 & 4.822 & 0.001 \\
\hline TL & 0.300 & 9.934 & 0.001 & 0.703 & 4.772 & 0.001 \\
\hline Cons*TL & - & - & - & -0.097 & -2.793 & 0.005 \\
\hline $\mathrm{R}^{2}$ & \multicolumn{9}{|l|}{$\mathrm{R}^{2}=0.28^{*}, \mathrm{~F}=95.643 \mathrm{P}=0.001$} & \multicolumn{2}{l}{$\mathrm{R}^{2}=0.291^{*}, \mathrm{~F}=67.245, \mathrm{P}=0.001$} \\
\hline$\Delta \mathrm{R}^{2}$ & \multicolumn{9}{|l}{$\Delta \mathrm{R}^{2}=0.011^{*}, \mathrm{~F}=7.803, \mathrm{P}=0.005$} \\
\hline
\end{tabular}

* Correlation is significant at 0.05 level (2-tailed) 
The results shown in table (11) cleared the role of TL and conscientiousness as independent variables (model 1). In addition to the interactive role of transformational leadership on the relationship between conscientiousness and intrapreneurship behavior (model 2). Although the positive relationship between conscientiousness and intrapreneurship behavior remains positive in the presence of TL as a moderator. Though, the results proved a negative interaction (beta= 0.097), reflecting a significant increase of $1.1 \%(\mathrm{P}=0.005)$.

Table 12: Moderated Regression Analysis Results (Agreeableness)

\begin{tabular}{|l|c|c|c|c|c|c|}
\hline \multirow{2}{*}{ Variable } & \multicolumn{3}{|c|}{ Model 1 } & \multicolumn{3}{c|}{ Model 2 } \\
\cline { 2 - 7 } & B & T value & p- value & B & T value & p- value \\
\hline Agreeableness & 0.207 & 6.087 & 0.001 & 0.602 & 4.498 & 0.001 \\
\hline TL & 0.325 & 10.680 & 0.001 & 0.758 & 5.224 & 0.001 \\
\hline Agree*TL & - & - & - & -0.104 & -3.048 & 0.002 \\
\hline $\mathrm{R}^{2}$ & \multicolumn{9}{|c|}{$\mathrm{R}^{2}=0.250^{*}, \mathrm{~F}=81.850, \mathrm{P}=0.001$} & $\mathrm{R}^{2}=0.264^{*}, \mathrm{~F}=58.582, \mathrm{P}=0.001$ \\
\hline$\Delta \mathrm{R}^{2}$ & \multicolumn{9}{|c|}{$\Delta \mathrm{R}^{2}=0.014^{*}, \mathrm{~F}=3.048, \mathrm{P}=0.002$} \\
\hline
\end{tabular}

* Correlation is significant at 0.05 level (2-tailed)

The results shown in table (12) showed the influence of agreeableness and TL as independent factors on the dependent variable (model 1). Furtheremore, it shows the role of $\mathrm{TL}$ as a moderator on the relationship between agreeableness and intrapreneurship behavior (model 2). The agreeableness-intrapreneurship behavior relationship remains positive in the presence of transformational leadership as a moderator. Though, the results showed a negative interaction (beta= $0.104)$, with a significant increase of $1.4 \%(\mathrm{P}=0.002)$.

\section{5- Discussion}

The first five hypotheses were elaborated to achieve the objective of investigating the organizational and individual determinants of employees' intrapreneurship behavior in Egyptian organizations. Furthermore, H6 was drawn to examine the conditions upon which the suggested determinants may level up those behaviors. The results came to support most of the study hypotheses, either full or partial support, while rejecting hypothesis 5 as follows:

H1 proposed that the more organizations enable a favorable psychological safety climate for their employees, the more they will exhibit intrapreneurship behaviors. The results proved this claim 
correct. The findings emphasized that the more employees work in an environment which enables them to feel free taking risks, making some mistakes, feeling safe trying new methods in doing their work, introducing tough and complex problems, and not feeling rejected by others, the more they will exhibit intrapreneurship behaviors.

The above result is consistent with both of the norm of reciprocity and the social exchange theory (Blau, 1964; Gouldner, 1960), which indicate that the relationships between organizations and their individuals, would be then exchanged and reciprocated either in positive or negative relations, attitudes or behaviors, relying on their positive or negative experiences with this organization. Hence, the more the organization will enable favorable environment for psychological safety for its employees, the more those employees will react back by exhibiting positive behaviors. This would be done through engaging in risk taking, proactiveness and innovativeness practices. The above result is also consistent with the streams of research which proved this positive effect (e. g. Frazier, et al., 2017; Mahmoud et al., 2018; Monfared, et al., 2019; Newman, et al., 2017).

Though a positive organizational climate for psychological safetyemployees' intrapreneurship behavior relationship was recorded, yet this relationship is weak $\left(\mathrm{R}^{2}=10 \%\right)$. Meaning that some other factors may also play important roles in explaining the variances in the dependent variable, and that organizational climate is not enough by itself to guarantee high levels of intrapreneurship behaviors. This result is consistent with the current study claims that individual factors may also represent important determinants for employees' intrapreneurship behaviors as will be presented in the following.

$\mathrm{H} 2$ and 3 were also elaborated to examine the effect of some individual factors on employees' intrapreneurship behaviors. It was argued that the more individuals feel a sense of psychological ownership (H2), and the more they have a high sense of achievement motivation (H3), the more they will be involved in intrapreneurship behavior. The results for both hypotheses were supported, where psychological ownership explained $44 \%$ of the variance in employees' intrapreneurship 
behaviors $\left(\mathrm{R}^{2}=44 \%\right)$, while achievement motivation explained $36 \%$ of this variance $\left(\mathrm{R}^{2}=36 \%\right)$.

$\mathrm{H} 2$ result came in accordance with the few prior research that indicated the significant role of psychological ownership on intrapreneurship behavior, and its dimensions (e. g. Badoiu, et al., 2020; Shaikh, et al., 2019; Slamti, 2020). This finding could be justified by referring to Avey and his colleagues' study (2009), who claimed that employees' feelings of ownership imply their feelings of territoriality towards the organizations' resources, in addition to their promotive feelings towards it. By applying this notion to the current study findings, it could be said that when employees feel the sense of ownership towards their organization, this would satisfy their feelings of territoriality over the resources of the organization, they would then try to protect those resources, and decide how to allocate and use them. Additionally, it would also satisfy some promotive positive feelings such as selfefficacy, accountability, belongingness and self- identity.

The social identity theory would also justify the above positive result. It indicates that individuals who identify and merge themselves with their organizations, will then work for the benefit of this organization. They would also feel its success as their own gainings, and vice versa (Ashforth and Mael, 1989; Dutton; Dukerich and Harquail, 1994; Turner; Hogg; Oakes; Reicher and Wetherell, 1987). By applying this idea to the results of the current study, it would be implied that the increased intrapreneurship behavior, will be determined by their sense of belonging and oneness to the organization, and hence, will act for the interest and benefit of it.

As per $\mathrm{H} 3$, some quantitative and qualitative research have cleared the role of self-motivation and motivational antecedents in explaining the variance of employees' intrapreneurship behaviors (e. g. Ali, et al., 2020; Badoiu, et al., 2020; Nessen, et al., 2019). Interstingly, other few research emphasized on the role of achievement motivation in raising up employees' intrapreneurship intentions, and revealed contradictory results (Shaikh, et al., 2019; Razavi and Ab Aziz, 2017). Hence, the current study furtherly examined this lacked relationship (H3) and came to support the hypothesis. This result could be explained by 
referring to the Mclleland's theory. It would be claimed that employees enjoying accomplishing difficult challenges, improving their performance, and seeking for feedback about their progress, will practice high intrapreneurship behaviors. In other words, employees having high sense of achievement motivation would practice innovative ways in accomplishing their jobs. They would also take risks and be more proactive in resolving problems and achieving their tasks with the best favorable innovative ways.

Personality traits have been other individual factors that were investigated as important antecedents for explaining the variance in employees' intrapreneurship behaviors. Both of hypotheses 4 and 5 were drawn to capture these relationships. It was claimed by the current research that extrovert, openned to experience, emotionally stable and conscientious people are more engaged in practicing intrapreneurship behaviors (H4); whereas agreeable people are less engaged in such behaviors (H5). The results came to support $\mathrm{H} 4$ partially, while rejecting $\mathrm{H} 5$.

As expected, the results proved the extraversion, emotional stability, and conscientiousness-employees' intrapreneurship behaviors positive relationships correct. The results were in the same line of prior research, which indicated these positive effects (e. g. Alam, et al., 2020; Di Fabio and Saklofske, 2019; Duradoni and Di Fabio, 2019a; b; Woo, 2018). These results would be also explained and justified by the claims drawn by Farrukh and his colleagues (2016), in which extroverts and emotionally stable persons would be more inclined and more motivated in practicing new ways doing their jobs, finding opportunities and practicing intrapreneurship behaviors without fear of failure or avoiding problems. Also, conscientious persons who have high motivation and are oriented by accomplishing objectives, would be the ones who are more inclined practicing novel ways rather than the old ones (Farrukh et al., 2016; Sinha and Srivastava, 2013).

Regarding the openness to experience trait and differing from other studies that have found positive effects (e.g. Alam, et al., 2020; Farrukh, et al., 2016; Woo, 2018), an unexpected negative relationship was recorded by the current study. Meaning that persons who exhibilt a low 
level of openness to experience, would be more engaged in intrapreneurship behavior. This finding indicates that practical persons, who have narrow interests, rather than being openned to experience persons, will practice this kind of behavior. This unexpected result imply that some other factors or favorable situations would help practical persons engaging in this behavior, such as the presence of an effective leader, who may encourage them experiencing proactive and innovativeness behaviors. This claim was also supported by the interactive role of TL in increasing such negative relationship, as will be discussed later while presenting H6 findings.

As per the agreeableness dimension (H5), a positive relationship was recorded. Meaning that agreeable people engage more in intrapreneurship behaviors. This result indicates that agreeableness explains $7.6 \%$ of the variance in intrapreneurship behaviors, and differs from prior studies, who came to find no significant relationship between agreeableness and innovative performance (Rodrigues and Rebelo, 2019), or a negative relationship with intrapreneurship behavior (Farrukh, et al., 2016).

Although $\mathrm{H} 5$ result was different from the relationship proposed by the current study, still this finding could be explained. Although agreeable persons would give priority to others' feelings, help and cooperate them, this would not be an obstacle for trying new work methods, innovate new ways and novel ideas while practicing their work. Nevertheless, this would rather encourage agreeable persons help their colleagues trying new methods and cooperate with them doing their work in easier and more effective ways.

By looking deeply into the personality traits-intrapreneurship behavior relationships, it could be noticed that conscientiousness was found to explain almost $14 \%$ of the variance in intrapreneurship behaviors, while extraversion, emotional stability, and agreeableness explained $1 \%, 5.6 \%$ and $7.6 \%$ of this variance. Additionally, a $1.6 \%$ negative effect of openness to experience on employees' intrapreneurship behaviors was noted. Although those traits explained the variance in employees' intrapreneurship behaviors, yet the relationships are found to be moderate and weak. This could be explained that other individual and 
organizational factors (i. e. psychological safety, psychological ownership and achievement motivation) may also play important roles in explaining this variance, in addition to other types of personalities that would furtherly be most influential in getting employees' practicing these kinds of behaviors. An obvious example of such types is the one suggested by Rodrigues and Rebelo (2019), who found that proactive personality is the most influential, and the valid predictor of innovative performance over and above the other big five personality traits. Other examples would be the personality characteristics suggested by Monfared and his colleagues (2019), such as ethical behavior, listening, coordination, empathy, hope for success, and persistence.

Furthermore, these findings could be consistent with other prior research, which have also found weak relationships of the big five personality traits on employees' intrapreneurship behaviors (e. g. Duradoni and Di Fabio, 2019a; Rodrigues and Rebelo, 2019). It would be also suggested that these relationships could be mediated by other factors to explain the relationship, such as intrapreneurial self capital (Duradoni and Di Fabio, 2019a), and emotional intelligence (Di Fabio and Saklofske, 2019). They would be also moderated by other factors to be strengthened, such as transformational leadership, as suggested by the current study.

Nevertheless, that organizational and individual determinantsemployees' intrapreneurship behavior relationships seem to be direct, they have been also challenged by the researchers to examine the conditions that could furtherly strengthen or weaken these direct relationships. It was claimed by prior research (e. g. Badoiu, et al, 2020; Buekensa, 2014) that managerial support, effective leadership, and managers' role in encouraging talented innovative employees is crucial. Specifically, studies have investigated the role of transformational leaders in leveling up employees' intrapreneurship behavior, either directly or indirectly in developed (e. g. Watts, et al, 2020) and transition countries (e. g. Khan, et al., 2020).

So far, those recent streams of research have not emphasized on TL as a moderator on these relationships. Therefore, and referring to the transformational leadership theory (Avolio and Bass, 2002), the current 
research proposed H6. The results have shown mixed results, and supported some of the above claims, hence accepting H6 partially as follows:

Intersetingly, it could be noted from the study results that although the organizational climate-intrapreneurship behavior relationship was positive, yet the inclusion of TL as an interactive variable has turned this positive relationship into a non-significant negative one. Nevertheless, the significant interaction increases from $20.4 \%$ to $21.7 \%$. Meaning that the role of TL as a moderator in this relationship is very crucial and encompasses the direct role of psychological climate in explaining the variance in intrapreneurship behavior. Furtheremore, the role of TL has the greater effect in increasing intrapreneurship behavior, rather than the role of climate. In other words, the relationship is conditioned on the presence of a transformational leader who helps his subordinates finding meanings of their jobs, feeling a sense of security being around him, developing themselves, motivating them to think differently of old problems and issues, and stimulating them dealing with tough and difficult issues.

The results also showed that psychological ownership on its own has a significant positive effect on employees' intrapreneurship behaviors ( $b=0.492, \mathrm{P}=0.001)$. But, while incorporating TL as a moderator, still this direct relationship remains positive, whereas the interaction is not significant. This means that TL failed to play the interactive role, while employees' feelings of ownership towards their organization encompasses the role of TL. In other words, psychological ownership feelings are sufficient by their own to stimulate employees practice intrapreneurship behaviors. This would be explained by both of social identity and social exchange theories, meaning that when employees have confidence feelings in their abilities, additionally, when they feel their belongingness to their organization as their home, and define themselves with it, they would behave for its interest. Furtheremore, they may exchange their favorable feelings towards it, by being more involved in activities and behaviors that may contribute to achieving its goals and success. 
As per each of achievement motivation, conscientiousness, and agreeableness, the results proved a significant positive relationship between achievement motivation and intrapreneurship behavior $(b=0.462, p=0.001)$, this relationship remains positive within the interaction $(b=0.659, p=0.001)$. The findings have additionally cleared a significant positive effect of conscientiousness on intrapreneurship behavior $(b=0.289, p=0.001)$, and remains positive within the interaction $(b=0.653, p=0.001)$. Furtheremore, the influence of agreeableness on intrapreneurship behavior is positively significant $(b=0.207, p=0.001)$, and remains positive within the interaction $(b=0.602, p=0.001)$. Though the results have also proved the interactive role of TL on the above relationships, yet the significant interaction is negative. This means that the leader would decrease his main roles, while increasing his delegating role, by giving some empowerment to those conscientious and agreeable subordinates, in addition to followers that have high achievement motivation. This would be explained by referring to both Mclleland and situational leadership theories (Hersey and Blanchard, 1988; Mclleland, 1965), meaning that when the leader perceives his subordinates as conscientious, agreeable and highly achieved persons, he would then decrease his interference, and would play the coach and mentor role. He would give them more authoroities and responsibilities doing and practicing intrapreneurship behaviors, without feeling fear of failure or punishment, in addition of giving them positive feedback about their own performance. In other words, this relationship is conditional upon the presence of a transformational leader who delegates some of his authorities and empowers and their followers.

Though that $\mathrm{H} 4$ revealed a positive effect of extraversion on intrapreneurship behavior, this relationship turned into a negative one in the presence of TL as an independent. Furtheremore, the interactive role of TL has strenthengned this negative relationship. This would be explained that the presence of TL would be effective in the case of decreased extraversion. This low level of extraversion from the one side, indicates a high level of introversion from the other side. Meaning that the more persons exhibit introvert traits, the more they would be engaged in intrapreneurship behaviors. Although the above-mentioned 
result would be unexpected, still it would be explained by reffering to the role of TL in stimulating and motivating introvert persons. In this situation, TL would help introvert followers overcome their shy and introversion, and being more proactive, and more innovative. In other words, even persons are introverts rather than extroverts, then the presence of an effective transformational leader would be a motivator or a catalyst for more engagement in intrapreneurship behavior, without fear of failure or a negative self-image.

The results have also proved that the interaction between TL and emotional stability is positive. This result indicates that TL plays the moderating role in strengthening emotional stability-intrapreneurship behavior's positive relationship. Meaning that transformational leaders will help and guide emotionally stable people, in addition of offering them the opportunities to practice these behaviors. This would be also supported by prior research who cleared the role of TL in motivating and stimulating employees' intrapreneurship behaviors (e. g. Farrukh, et al., 2019; Watts, et al., 2020). This may be also explained by both of the social exchange, and the transformational leadership theories (Avolio and Bass, 2002; Bass, 2000; Blau, 1964), referring that when emotionally stable employees feel that their leader encourages and stimulates them, they would more inclined to practice more positive behaviors, as a way of exchanging good relationships.

The openness to experience results refer to the role of TL in strengthening the negative relationship between openness to experience and intrapreneurship behavior. Nevertheless, this result was an unexpected one, still it would be explained by referring to the effective role of TL in the case of a decreased openness to experience level. Meaning that intrapreneurship behavior will be increased through the increased role of TL, which encompasses the role of openness to experience. Additionally, this negative relationship implies that those respondents would be more practical and may have narrow interests, rather than being highly openned to experience persons. This finding revealed that those practical persons' engagement in intrapreneurship behavior, is conditional upon the presence of a transformational leader. It also clears the crucial role of TL in 
motivating and stimulating those practical persons overcome their narrow interests and engage in such behaviors.

To sum up, it could be noticed the significance of both organizational and individual antecedents in determining the level of employees' intrapreneuship behaviors, especially in transition countries to guarantee higher levels of performance and productivity. Furthermore, the findings emphasized on some favorable conditions, upon which transformational leadership would increase these behaviors, while in some other situations it could not play the same expected moderating role in strengthening those relationships.

\section{6- Conclusion}

To conclude, it could be claimed that the current study has achieved its main objectives. The results cleared that although some organizational and individual variables are vital for determining and explaining the variance in employees' intrapreneurship behaviors, yet they are not only enough to guarantee higher levels of those behaviors. A specific kind of leadership (i.e. transformational leader) is also crucial to enhance and guarantee higher levels of these positive behaviors in some situations.

\section{7- Research Recommendations}

Depending on the above findings, some recommendations would be suggested to the organizational managers and leaders, in addition to the Egyptian government as follows:

- Directing managers and business leaders' attention towards the role of social exchange processes in raising up employees' intrapreneurship behaviors. Employees would exchange and reciprocate good practices and behaviors for good treatments of the organization. Accordingly, this raising could be done through enabling a supported environment, in which employees feel safe suggesting new work methods, making mistakes and trying new practices and techniques for accomplishing their goals, without being neglected or punished, as a result of the social exchange processes between employees and their organizations. This would have many positive effects for the organization, such as improving performance 
and productivity of the employees, in addition to increasing the organization's value and competitive advantage.

- Considering Lenovo Egypt (2020) as an obvious example of some organizations which are interested in enabling good practices for leveling up employees' intrapreneurship behaviors, the current study would recommend applying its effective policy regarding those behaviors. These practices could include stimulating and rewarding employees' creativity, innovation and learning to capture novel opportunities. Organizations may also enable favorable organizational learning environment, for acquiring experiences and crearting knowledge. This could be also done through empowering those intrapreneurs, motivating them, in addition to allowing them trying new techniques without fear of failure or punishments.

- Directing business leaders and managers' attention towards enhancing employees' identification feelings, which will in turn participate in the raise of those employees' positive behaviors. Meaning that when employees feel their belongingness and oneness to the organization, they would work for the collective. Therefore, managers and business leaders would work for increasing employees' feelings of their territoriality over the organization's resources, in addition to developing their awareness and belongingness to that organization, in which they feel that this organization is their home. They would also increase their confidence feelings, and their accountability. This could be done through acting for employees' benefits and needs, creating a sense of meaning of their work, stimulating them to engage in innovativeness, risk taking behaviors, and being more proactive. Furtheremore, they would play the mentor role for those employees, build respect and trust feelings, stimulate, and encourage them doing their work and improve their performance.

- Organizations would establish appropriate human resources policies and practices. This would include effective programs for recruiting, selecting and hiring highly achievement-oriented employees, in addition to giving more interest for the personality tests and interviews, in order to hire the ones who have the appropriate traits 
to engage and practice intrapreneurship behaviors, such as extrovert, emotionally stable, and intelligent persons. Organizations may also give more attention to training and development programs for stimulating and increasing those behaviors, this would be applied through various activities such as seminars, action learning programs and simulations.

- Giving more attention towards motivating intrapreneurs, this may be exercised through enabling highly achievement-oriented employees to practice intrapreneurship behaviors, giving them more novel and challenging missions, in addition to giving immediate feedback about their performance, and taking some corrective actions when necessary.

- Some other recommendations would be suggested for the Egyptian government. This may include governmental policies fostering and increasing intrapreneurship behaviors, such as offering special training and development programs for those employees on the national level, holding contests among different creative organizations trying to capture the best innovative ideas, enabling good environment for embracing, developing and implementing these innovative ideas and sharing knowledge, connecting and exposing those intrapreneurs with each other locally, and internationally within an Electronic Hub, in addition to praising and rewarding those novel ideas.

- Although the presidential program to qualify youth for leadership is playing a great role in preparing young people for managerial positions in governmental departments, yet, Egyptian government should also train those young candidates on creative and system thinking, and pay more attention towards the talent management program.

\section{8- Research Limitations}

Due to the exceptional conditions that faced the researchers during the period of conducting the study and collecting data (Covid 19 closings), a convenient sampling technique was conducted. This may affect the findings' generalization, however, the researchers tried to overcome 
this shortcoming, by getting a larger sample and a high response rate, through distributing handled questionnaires, in addition to the on-line ones.

\section{9- Suggestions for Future Research}

- This study recommends future research incorporate some mediating variables. These suggested factors would furtherly give more explanations to the organizational and individual determinantsintrapreneurship behavior relationships, especially with the weak relationship ones. Those mediating variables would include organizational identification, trust in the organization, fear of failure, and knowledge sharing behavior, in addition to intrapreneurial self capital, and emotional intelligence.

- Investigating other moderating variables that would furtherly strengthen the relationships between individual and organizational antecedents and intrapreneurship behaviors, such as other leadership types (i. e. servant leadership).

- Some prior research have revealed that proactive personality would have more influence, over the other big five dimensions in explaining the variance in the dependent variable (Rodrigues and Rebelo, 2019). Therefore, it could be suggested incorporating the proactive personality as an important personality type, and test its effect on the dependent variable, in addition to comparing the results with the big five dimensions results of the current study.

- More organizational and individual determinants could be tested, such as organizational support, and psychological empowerment. Furtheremore, the study recommends expanding the model by incorporating the effects of intrapreneurship behaviors, such performance, productivity, and organizational value.

- The study also recommends future research applying the proposed model on governmental institutions and exploring the impediments which would hamper employees' involvement in risk taking, innovative and proactive behaviors. This would help capturing the substantial differences between both of private and governmental 
sectors. It would also help comparing the results with the ones revealed by the current research.

- It would be also suggested applying the model of the study, by investigating the dimensions of the study variables, such as the psychological ownership, transformational leadership, and intrapreneurship behaviors' dimensions.

- Finally, to guarantee the generalization of the findings, the study recommends future research using random sampling techniques on some specific private sectors and comparing the results with the ones reached by the current study.

\section{References}

Agarwal, P. and Farndale, E. (2017). High-performance work systems and creativity implementation: the role of psychological capital and psychological safety. Human Resource Management Journal, 27 (3): 440-458.

Alam, M. Z.; Kousar, S.; Shabbir, A. and Kaleem, M. A. (2020). Personality traits and intrapreneurial behavior: Moderated role of knowledge sharing behavior in diverse group of employees in developing country. Asia Pacific Journal of Innovation and Entrepreneurship, 14 (1): 31-46.

Ali, M.; Mustapha, I.; Jaafar, J.; Hassan, M. and Ur Rehman, S. U. (2020). "Intrapreneurship among Malaysian organizations in retail industry". International Journal of Recent Technology and Engineering, 8 (6): 1913- 1925.

Andersson, M.; Moen, O. and Brett, P. O. (2020). The organizational climate for psychological safety: Associations with SMEs' innovation capabilities and innovation performance. Journal of Engineering and Technology Management, 55: 1-13.

Antoncic, B. and Hisrich, R. D. (2003). Clarifying the intrapreneurship concept. Journal of Small Business and Enterprise Development, 10 (1): 7-24. doi: 10.1108/14626000310461187 
Aris, A.; Rajah, N.; Abdullah, N. H. and Abdul Hamid, N. A. (2019). Training and development on innovative work behavior among public organization managers: The mediating effect of intrapreneurial competencies. International Journal of Engineering and Advanced Technology, 8 (5): 2769-2775.

Ashforth, B. E. and Mael, F. (1989). Social identity and the organization. Academy of Management Review, 14, 20-39.

Avey, J. B.; Avolio, B. J.; Crossley, C. D. and Luthans, F. (2009). Psychological ownership: Theoretical extensions, measurement and relation to work outcomes. Journal of Organizational Behavior, 30 (2): 173-191.

Avolio, B. J. and Bass, B. M. (2002). Developing potential across a full range of leadership: Cases on transactional and transformational leadership. Mahwah, NJ: Lawrence Erlbaum.

Badoiu, G. A.; Segarra-Ciprés, M. and Escrig-Tena, A. B. (2020). Understanding employees' intrapreneurial behavior: a case study. Personnel Review. Retrieved March, 2020 from https://www.emerald.com/insight/0048-3486.htm

Baer, M. and Frese, M. (2003). Innovation is not enough: Climates for Initiative and psychological safety, process innovations, and firm perforemance. Journal of Organizational Behavior, 24: 45 -68.

Bass, B. M. (2000). The future of leadership in learning organizations. Journal of Leadership Studies, 7 (3): 18-40.

Blau, P. M. (1964). Exchange and power in social life. New York: Wiley.

Boukamcha, F. (2019). The effect of transformational leadership on corporate entrepreneurship in Tunisian SMEs. Leadership and Organization Development Journal, https://doi.org/10.1108/LODJ-07-2018-0262

Brown, S. P. and Leigh, T. W. (1996). A new look at psychological climate and its relationship to job involvement, effort, and performance. Journal of Applied Psychology, 81: 358-368. 
Buekensa, W. (2014). Fostering intrapreneurship: The challenge for a new game leadership. Procedia Economics and Finance, 16: 580586.

Bysted, R. (2013). Innovative employee behavior: The moderating effects of mental involvement and job satisfaction on contextual variables. European Journal of Innovation Management, 16 (10): 268-284. doi:10.1108/EJIM-09-2011-0069

Chen, M.; Gao, X.; Zheng, H. and Ran, B. (2015). A review on psychological safety: concepts, measurements, antecedents and consequences variables. International Conference on Social Science and Technology Education.

Cronbach, L. J. (1951). Coefficient alpha and the internal structure of tests. Psychometrika, 16 (3): 297-334.

Daneji, A. M. and Bambale, A. J. (2019). Mediating effect of intrapreneurship on psychological ownership and teachers' in role performance.

The 1st International Conference on Business, Management and Information Systems. Available at SSRN: $\quad$ https://ssrn.com/abstract= 3487 $\underline{395}$ or http://dx.doi.org/10.2139/ssrn.3487395

De Vries, R. E.; Wawoe, K. W. and Holtrop, D. (2016). What is engagement? Proactivity as the missing link in the HEXACO model of personality. Journal of Personality, 84 (2): 178-193.

Di Fabio, A. and Saklofske, D. H. (2019). The contributions of personality traits and emotional intelligence to intrapreneurial self-capital: Key resources for sustainability and sustainable development. Sustainability, 11 (5): 1240-1254.

Douglas, E. and Fitzsimmons, J. (2013). Intrapreneurial intentions versus entrepreneurial intentions: Distinct constructs with different antecedents. Small Business Economics, 41 (1): 115132. 
Duradoni, M. and Di Fabio, A. (2019a). Intrapreneurial self-capital and sustainable innovative behavior within organizations. Sustainability, 11: 322 - 332.

Duradoni, M. and Di Fabio, A. (2019b). Intrapreneurial self-capital and connectedness to nature within organizations. Sustainability, 11: $3699-3710$.

Dutton, J. E.; Dukerich, J. M. and Harquail, C. V. (1994). Organizational images and member identification. Administrative Science Quarterly, 39: 239-263.

Edmondson, A. (1999). Psychological safety and learning behavior in work teams. Administrative Science Quarterly, 44 (2): 350-383.

Egypt Innovate, (2019). EgyptInnovate is the online innovation hub for Egypt. Where innovators and entrepreneurs get inspired, educated and connected. https://www.tiec.gov.eg/english/Programs/EgyptInnovate/Pag es/default.aspx

Farrukh, M.; Lee, J. W. and Shahzad, I. A. (2019). Intrapreneurial behavior in higher education institutes of Pakistan. The role of leadership styles and psychological empowerment. Journal of Applied Research in Higher Education, 11 (2): 273-294.

Farrukh, M.; Ying, C. and Mansori, S. (2016). Intrapreneurial behavior: an empirical investigation of personality traits, Management and Marketing. Challenges for the Knowledge Society, 11 (4): 597-609.

Fornell, C. and Larcker, D. F. (1981). Evaluating structural equation models with unobservable variables and measurement error. Journal of marketing research, 39-50.

Frazier, M. L.; Fainshmidt, S.; Klinger, R. L.; Pezeshkan, A. and Vracheva, V. (2017). Psychological safety: A meta-analytic review and extension. Personnel Psychology, 70: 113-165.

Goldberg, L.R. (1990). An alternative "description of personality: The big-five factor structure, Journal of personality and social psychology, 59 (6): 1216-1229. 
González-Serrano, M. H.; Moreno, F. C.; Valantine, I. and Hervás, J .C. (2019). How to detect potential sport intrapreneurs? Validation of the intrapreneurial intention scale with sport science students. Journal of Entrepreneurship and Public Policy, 8 (1): 4061.

Gouldner, A. W. (1960). The norm of reciprocity: A preliminary statement. American Sociological Review, 25: 161-178.

Hersey, P. and Blanchard, K. (1988). Management of organizational behavior: Utilizing human resources. Englewood Cliffs, NJ: Prentice-Hall.

Inno Egypt, (2017). Inno Egypt. Incubate your idea. About Inno Egypt. Toward competent innovation and knwledge-based economies in Egypt via business incubation and startups. http://euinnoegypt.net/about/

Jessri, M.; Kosmidou, V. and Ahuja, M. K. (2020). Employees' decision to participate in corporate venturing: A conjoint experiment of financial and non-financial motivations. Journal of Business Venturing Insights, 13: (C). DOI: 10.1016/j.jbvi.2020.e00161

John, O. P. and Srivastava, S. (1999). The Big Five Trait taxonomy: History, measurement, and theoretical perspectives. In L. A. Pervin and O. P. John (Eds.), Handbook of personality: Theory and research, 102-138. Guilford Press.

Kanten, P. and Alparslan, A. M. (2013). Proactive behavior scale: A study of validity and reliability. Selçuk Üniversitesi Sosyal Bilimler Meslek Yüksekokulu Dergisi, 16: 21-43.

Kark, R. and Carmeli, A. (2009). Alive and creating: The mediating role of vitality and aliveness in the relationship between psychological safety and creative work involvement. Journal of Organizational Behavior. 30

(6): 785-804. DOI: $10.1002 /$ job.571

Khan, M. A.; Ismail, F. B.; Hussain, A. and Alghazali, B. (2020). The interplay of leadership styles, innovative work behavior, 
organizational culture, and organizational citizenship behavior. SAGE Open, 10 (1): 1-16.

Khan, M. J.; Aslam, N. and Riaz, M. N. (2012). Leadership styles as predictors of innovative work behavior. Pakistan Journal of Social and Clinical psychology, 9 (2). https://www.researchgate.net/publication/234092637 _Leadership_Styles_as_Predictors_of_Innovative_Work_Behavior.

Kahn, W.A. (1990). Psychological conditions of personal engagement and disengagement at work. Academy of Management Journal, 33 (4): 692-724.

Lee, K.; Makri, M. and Scandura, T. (2019). The effect of psychological ownership on corporate entrepreneurship: comparisons between family and non-family top management team (TMT) members. Family Business Review, 32 (1): 10-30.

Lenovo Tech Today, (2020). How to foster a culture of intrapreneurship-Lenovo Egypt. https://www.lenovo.com/eg/en/solutions/smb/how-fosterculture-intrapreneurship

Mahmoud, M. A.; Ahmad, S. and Poespowidjojo, D. A. (2018). The role of psychological safety and psychological empowerment on intrapreneurial behavior towards successful individual performance: A conceptual framework. Sains Humanika, 10 (3): 65-72.

Marques, C. S.; Marques, C. P.; Ferreira, J. J. and Ferreira, F. A. (2019). Effects of traits, self-motivation and managerial skills on nursing intrapreneurship. The International Entrepreneurship and Management Journal, 15:733-748. https://doi.org/10.1007/s11365-018-0520-9 
Maslow, A. H. (1943). A theory of human motivation. Psychological Review, 50: 370-396.

McClelland, D. C. (1965). Toward a theory of motive acquisition. American Psychologist, $20 \quad$ (5): $321-$ 333. https://doi.org/10.1037/h0022225

Moghaddas, S. Z.; Tajafari, M. and Nowkarizi, M. (2020). Organizational empowerment: A vital step toward intrapreneurship. Journal of Librarianship and Information Science, 52 (2): 529-540.

Monfared, M.; Khorakian, A.; Shirazi, A. and Maharati, Y. (2019). Identifying of intrapreneurship behaviors: Case of country in transition economy. Modern Applied Science, 13 (5): 1-12.

Moriano, J. A.; Molero, F.; Topa, G. and Mangin, J. P. (2014). The influence of transformational leadership and organizational identification on intrapreneurship. International Entrepreneurship and Management Journal, 10 (1): 103-119.

Mustafa, M.; Martin, L. and Hughes, M. (2016). Psychological ownership, job satisfaction, and middle manager entrepreneurial behavior. Journal of Leadership and Organizational Studies, 23 (3): 272287.

Nessen, P. C.; Caniëls, M. C.; Vos, B. and de Jong, J. P. (2019). The intrapreneurial employee: toward an integrated model of intrapreneurship and research agenda. International Entrepreneurship and Management Journal, 15: 545-571. https://doi.org/10.1007/s11365-018-0552-1.

Newman, A.; Donohue, R. and Eva, N. (2017). Psychological safety: A systematic review of the literature. Human Resource Management Review, 27 (3): 521-535.

Ntoyanto-Tyatyantsi, N. (2018). Exploration of intrapreneurship practicies to improve service delivery within O.R. TAMBO district municipality. Submitted in accordance with the requirements for the degree of Master of Commerce in the subject of Business Management at the University of South Africa. 
O'Driscoll, M. P.; Pierce, J. L. and Coghlan, A-N (2006). The psychology of ownership: Work environment structure, organizational commitment, and citizenship behaviors. Group and Organization $\begin{array}{llll}\text { Management, } \quad 31 & \text { (3): } \quad 388-416 . & \text { DOI: }\end{array}$ $10.1177 / 1059601104273066$

Pierce, J. L.; Kostova, T. and Dirks, K. T. (2001). Toward a theory of psychological ownership in organizations. Academy of Management Review, 27: 298-310.

Pierce, J. L.; Kostova, T. and Dirks, K. T. (2002). The state of psychological ownership: Integrating and extending century of research. In Press: Review of General Psychology.

Pierce, J. L.; O'Driscoll, M. P. and Coghlan, A. M. (2004). Work environment structure and psychological ownership: The mediating effects of control. Journal of Social Psychology, 144: 507-534.

Rastbin, P. (2016). To investigate the relationship between transformational leadership with inter-organizational entrepreneurship (A Case Study: Kurdistan Province Industrial Firms). Journal of Tourism and Hospitality, 5 (1): 190-197.

Razavi, S. H. and Ab Aziz, K. (2017). The dynamics between entrepreneurial orientation, transformational leadership, and intrapreneurial intention in Iranian R\&D sector. International Journal of Entrepreneurial Behavior and Research, 23 (5): 769792.

Rodrigues, N. and Rebelo, T. (2019). Predicting innovative performance through proactive personality: Examining its criterion validity and incremental validity over the five-factor model. International Journal of Selection Assessment, 19 (27): 1-8. https://doi.org/10.1111/ijsa.12232

Sadeghpour, M.; Cherabin, M.; Shekari, G. A. and Del, A. Z. (2019). Identifying factors affecting entrepreneurship and organizational agility (Case study: Mashhad University of Medical Sciences. Future of Medical Education Journal, 9 (4): 34- 45. 
Sekaran, U. and Bougie, R. (2016). Research methods for business: A skill building approach. John Wiley and sons.

Shafique, I. and Kalyar, M. N. (2018). Linking transformational leadership, absorptive capacity, and corporate entrepreneurship. Administrative Science, 8 (2): 1-17.

Shani, A. B.; Chandler, D.; Coget, J-F. and Lau, J. B. (2009). Behavior in organizations. An experimental approach. Ninth Ed. McGraw-Hill International Edition.

Schachtebeck, C.; Groenewald, D. and Nieuwenhuizen, C. (2019). Intrapreneurial orientation in small and medium-sized enterprises: An exploration at the employee level. Acta Commercii, 19 (2): 1-13. https://doi.org/10.4102/ ac.v19i2.638

Shaikh, N. F., Nili, M., Dwibedi, N., and Madhavan. S. S. (2019). "Measuring entrepreneurial and intrapreneurial intentions in student pharmacists". American Journal of Pharmaceutical Education, 1-20. DOI: https://doi.org/10.5688/ajpe7624

Schein, E. H. and Bennis, W. G. (1965). Personal and organizational change through group methods: The laboratory approach. New York, NY: Wiley.

Sieger, P.; Zellweger, T. and Aquino, K. (2013). Turning agents into psychological principals: Aligning interests of non-owners through psychological ownership. Journal of Management Studies, 50, 361-388. doi:10.1111/joms.12017

Sinha, N. and Srivastava, K.B. (2013). Association of personality, work values and socio-cultural factors with intrapreneurial orientation. Journal of Entrepreneurship, 22 (1): 97-113.

Slamti, F. (2020). Linking transformational leadership, sense of belonging and intrapreneurship. 51st International Scientific Conference on Economic and Social Development - Rabat. 
Stull, M. and Singh, J. (2005). Internal entrepreneurship in nonprofit organizations: Examining the factors that promote entrepreneurial behavior among employees. Conference: Babson Kauffman Entrepreneurship Research Conference At: Wellesley, Massachusetts. Volume: Frontiers of Entrepreneurship Research.

Turner, J. C.; Hogg, M. A.; Oakes, P. J.; Reicher, S. D. and Wetherell, M. S. (1987). Rediscovering the Social Group: A Self-Categorization Theory. Oxford and New York: Blackwell.

Valka, K.; Roseira, C. and Campos, P. (2020). Determinants of university employee intrapreneurial behavior: The case of Latvian universities. Industry and Higher Education, 34 (3): 190-202. https://doi.org/10.1177 \%2F0950422219897817

Valsania, S. E.; Moriano, J. A. and Molero, F. (2016). Authentic leadership and intrapreneurial behavior: cross-level analysis of the mediator effect of organizational identification and empowerment. International Entrepreneurship and Management Journal, 12 (1): 131-152.

Van Dyne, L. and Pierce, J. L. (2004). Psychological ownership and feelings of possession: Three field studies predicting employee attitudes and organizational citizenship behavior. Journal of Organizational Behavior, 25: 439-459.

Walberg, V. (2019). Organizations' best practice to reap the benefits of employees' intrapreneurial behavior: A case study. MSc. in Innovation and Entrepreneurship. Faculty of Mathematics and Natural Sciences. University of Oslo.

Watts, L. L.; Steele, L. and Den Hartog, D. N. (2020). Uncertainty avoidance moderates the relationship between transformational leadership and innovation: A meta-analysis. Journal of International Business Studies, 51: 138-145•

Woo, H. R. (2018). "Personality traits and intrapreneurship: the mediating effect of career adaptability". Career Development International, 23 (2): 145-162. 
(World Bank, 2020). Catalysing entrepreneurship for job creation. https://projects.worldbank.org/en/projects-operations/projectdetail/P162835

(World Bank, 2019 a). Innovation and entrepreneurship. Innovation and entrepreneurship are recognized as key building blocks of competitive and dynamic economies. https://www.worldbank.org/en/topic/ innovationentrepreneurship

(World Bank, 2019 b). Egypt's economic update - October 2019. https://www.worldbank.org/en/country/egypt/publication/ec onomic-update-october-2019

(World Bank, 2019 c). The World Bank in Egypt. The World Bank group's current engagement is guided by Egypt country partnership framework, and the performnace and learning review. https://www.worldbank.org Len/country/egypt/overview\#3 


\section{المحددات التنظيمية والفردية المؤثرُة على السلوك الريادي للعاملين في منظمات القطاع الخاص المصرية \\ د. غادة عادل عطية أد. علي عبد الهادي مسلم}

ملخص البحث باللغة العربية

تتناول الدراسة الحالية الدورالذي تلعبه بعض العوامل التنظيمية والفردية في زيادة السلوك الريادي للعاملين في المنظمات،

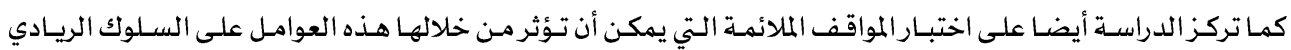

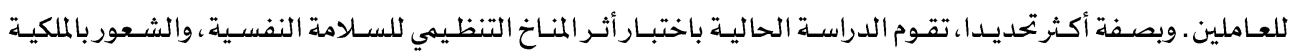

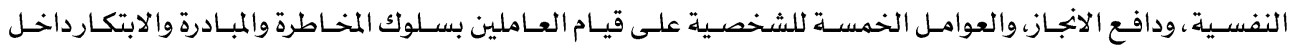
المنظمات. وتقوم الدراسة أيضا باختباردورالقيادة التحويلية كوسيط تفاعلي في تقوية هذه العلاقات المباشرة.

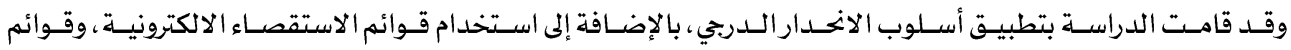

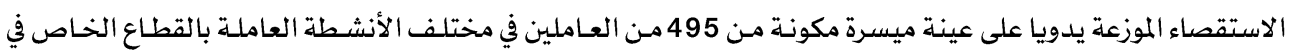

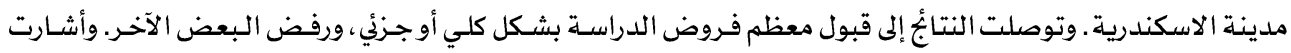

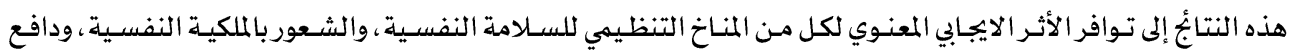

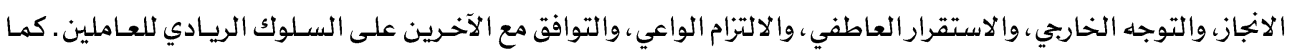

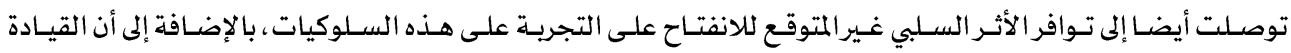

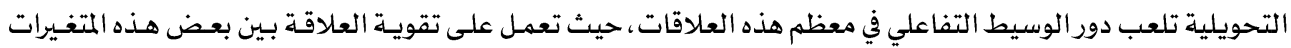
التنظيمية والفردية وبين السلوك الريادي للعاملين.

الكلمات الدالة: المناخ التنظيمي للسلامة النفسية، الشعور بالملكية النفسية، دافع الانجاز، الأبعاد الخمسة للشخصية، السلوك الريادي للعاملين ، القيادة التحويلية.

\section{Suggested Citation according to APA Style}

Atteya, G. A. and Messallam, A. A. (2021). Organizational and Individual Determinants of Employees' Intrapreneurship Behavior in Private Egyptian Organizations. Journal of Alexandria University for Administrative Sciences, Faculty of Commerce- Alexandria University 58(2), 1 - 56. 